\title{
Bosphorus Coastal Road and Settlements Between Beşiktaş and Bebek in 1939 Plan
}

\author{
Sezgi Giray Küçük ${ }^{1 \odot}$ \\ ${ }^{1}$ Asst. Prof. Dr., Architectural Restoration Programme, Vocational School, Mimar Sinan Fine Arts University, Turkey. E-mail: \\ sezgi.giray.kucuk@msgsu.edu.tr
}

\begin{abstract} Purpose

The aim of the study is to question whether this plan, which was signed by Henri Prost and showing the settlements between Beşiktaş and Bebek on the European side of the Bosphorus in detail and explains them in cross-sections, is implemented or not, and to reveal the effect of the plan on the formation of current state of the Bosphorus coasts. In the study, which decisions are taken during the planning process are also questioned.

Design/Methodology/Approach

In the study, the city centers of Beşiktaş, Ortaköy, Arnavutköy, Kuruçeşme, Bebek and the settlements between them and the conditions of the coastal road before, in and after 1939 are examined with the help of maps and aerial photographs. With the aerial photographs that have survived until today, the physical change of the urban texture over time and its current situation are also revealed.

\section{Findings}

As a result of the examination, it was determined that most of the plan, which was approved in 1939, was implemented between 1956-1958, during the Menderes period. In this process, many settlements lost their original urban texture, historical structures, and architectural identities. It can be said that the seeds of the pile road, which was built during the Dalan period and cut the connection of the mansions with the sea, was planted with this plan. It was also possible to obtain some clues about the planning approach of the Prost period from this plan. Accordingly, it can be listed as opening squares, turning dead-end streets into streets, widening the streets, and cleansing industrial-related spaces from the coastline. The fact that these plan decisions are encountered in other regions of Istanbul during the Prost period, suggests that although Prost did not draw the 1939 plan, it had a share in its design.

\section{Research Limitations/Implications}

Due to the lack of a clear aerial photograph or map after 1939 until 1955, the year in which the changes foreseen in this plan were applied could not be determined clearly, and the time interval was stated.

\section{Originality/Value}

This plan, being one of the first steps of the Bosphorus coastal regulations on the European side, is an original document that has not been evaluated in previous research. This plan was drawn when Henri Prost was working as an urban planning specialist in the Istanbul Municipality Zoning Directorate and it bears the signature of Prost's approval.
\end{abstract}




\section{INTRODUCTION}

In the historical perspective, Istanbul, like all Islamic cities, has the appearance of a spontaneous city, in other words, an unplanned city (Kuban, 1996). In time, due to fires and earthquakes, the buildings were demolished and the plan of Istanbul was renewed as a grid system regionally. In the $19^{\text {th }}$ century, the first planned studies on the urban plans of Istanbul began. Map studies initiated during the $2^{\text {nd }}$ Mahmut period (1808-1839) are indicative of the transition of Istanbul to the planned development period. The first map was drawn to Helmuth Von Moltke by the Ottoman State. Moltke was sent to Istanbul in 1835 by the Prussian government as a consultant to the Ottoman army. During his stay in Istanbul, he prepared a zoning plan alongside the map. This study, which could be considered as the first zoning plan in the whole city scale in the Ottoman Empire, maintained its effect for a while and at least created an acceleration that continues its effect for similar studies in Istanbul today (Beydilli, 2005). However, the proposals prepared without coming to Istanbul were prepared by ignoring the Istanbul topography consisting of hills and valleys, they couldn't form a holistic plan (Akpınar, 2014). In 1933 Herman Elgötz from Germany, Alfred Agache and J.H. Lambert from France was invited for urban problems. It is seen that the reports they prepared as a result of their investigations are aimed at general level and urban transportation problems (Salman, 2004). Their recommendations in areas such as growth, transportation, historic preservation and the creation of regions have not been implemented, but their reports have survived to the present day (Çelik, 2015). Dr. Ing. M. Wagner's work titled "Plan of Istanbul and its environs" is based on environmental analyzes and emphasizes the necessity of protecting agricultural lands. This plan proposal was not adopted.

In 1936, the Municipality of Istanbul called on Henri Prost, the chief urbanist of Paris, to prepare Istanbul's master plan. Prost have made plans, sketches, projects and proposals about Ayasofya, Atmeydanı, Archeology Park, Atatürk Boulevard, Fatih and Taksim Squares, Beyoğlu neighborhood, Bedesten Metro stop, Grand Bazaar and Eminönü Square. He also has studies about the road system. Atatürk Boulevard, YenikapiAksaray road, Millet Street, the coastal road along the coasts of the Marmara Sea and the Golden Horn, Yenikapı-Yeşilköy airport road are among these studies (Gül, 2013). In addition to these, Prost has also made some studies on the planning of the Bosphorus, one of the historical and culturally valuable areas of Istanbul.

Bosphorus which was opened to settlement after the conquest of Istanbul, became a suburb of the city in the $19^{\text {th }}$ century. With the establishment of the Republic in 1923, its population increased, its urban texture changed in relation to the planning and urban development of Istanbul. In this process, the coasts of the Bosphorus started to be preferred for permanent residential use (Aysu, 1989). This 
situation led to an increase in population density and planning studies in these areas. Prost's work on the Bosphorus coincides with this period. In the 1/5000 scale master plan report completed by Prost in October 1937 and approved in 1939, it was proposed about Bosphorus, only to remove the warehouses and industrial establishments on the coast (Prost, 1938). Prost then discussed the planning of the settlements along the Bosphorus, dealing with this from 1939 to 1948 (Bilsel, 2010). He delivered the development plan in 1948. According to this plan, mansions, which are unique to the Bosphorus, are architectural heritage buildings and their protection is also important. Prost showed a planning approach that emphasizes sea, green texture and mansions, in Beşiktaş, Beylerbeyi, Kuruçeşme, Arnavutköy, Bebek, in its reports. According to Prost, white colour should be used for palaces and mansions in the Bosphorus whereas the other buildings should be red, yellow, gray according to the traditions. These structures should be carefully planned by trained architects in order not to damage the view of the Bosphorus. Prost's proposal is a realistic and less interventionist approach that aims to protect the urban texture consisting of houses and historic mansions along the coasts of the Bosphorus with its historicist and conservative approach (Coşkun, 2017). Prost stated that the upper and lower cornices should be planned alongside the coastal road in order to create alternatives to the coastal road which is the only way to reach the Bosphorus villages. He envisions a triple cornice model inspired by the Côte de Variose regulations in France on the Bosphorus (Salman, 2004).

Another contribution of Prost to the studies on the Bosphorus, is the $1 / 2000$ scale plan approved in 1939 (Figure 1). This plan was drawn up in October 1938 approved and signed by Henri Prost in December 1938 on condition that the two regions (Ortaköy and Beşiktaş) are revised again, and in June 1939, the same regions were approved by the zoning manager. The plan is about the arrangement of the coastal settlements in the European side of Istanbul, from Beşiktaş to Bebek, their nearby surroundings and the coastal road (Atatürk Library, Hrt_006246). Although it covers a large area, a detailed planning has been made for each settlement. In the plan, existing streets, squares, building blocks, green areas, monumental structures are drawn, and the structures planned to be built are expressed with writing. The plan has been made more defined by supporting contour lines and sections. The planned changes are indicated with red lines on the plan used as a base. This original plan, which has not been the subject of any publication until today, has been the starting point of this study. In this study, the issues taken into account in the design of the mentioned plan are tried to be revealed. It is questioned whether this plan was implemented, in what period it was implemented, and how this planning affects the urban identity of the region. Accordingly, an answer is sought to the question of what the share of the plan in the formation of the present-day Bosphorus coastline is. 


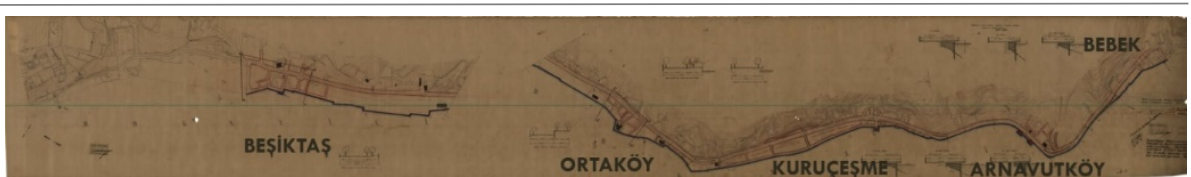

Information about the planning of the Bosphorus is generally available in publications on the planning and reconstruction of Istanbul (Doğusan, 2004; İstanbul'un kitabı, 1957; Tekeli, 2009; Ünsal, 1968) or directly in publications related to the planning of the Bosphorus (Ylldiz et al., 2018; Salman, 2004; Salman \& Kuban, 2006; Diker et al., 2008; Ergen, 2005). However, in publications directly related to the planning of the Bosphorus, it generally emphasizes the post-1950 period when the threats related to the protection of the Bosphorus due to the density of the population, and generally examines the role of laws in the change of the region. Prost period Istanbul plans were also investigated in the study. Many researchers such as Akpınar (2010), Bilsel (2010), Bilsel \& Zelef (2011), Cansever (1994), Coşkun (2017), Enlil (2011), Gül \& Lamb (2004), Suher (1993), Uluengin \& Turan (2005), Uluskan (2007), Tekeli (1993) have worked on this issue. However, the map that constitutes the subject of this study has not been found among these publications. Besides, there are publications examining the physical change of Bosphorus villages in the study area. In the context of historical development, urban change and transformation and protection of historical regions, Arnavutköy (Ünal, 2011; Ansel, 2016), Beşiktaş (Gökyay, 2009; Özsoydan, 2018; Metin, 2010; Üresin, 2019), Kuruçeşme and Ortaköy (Atalan, 2008) has been the subject of many publications. However, there is no publication that collectively deals with the change of settlements between Beşiktaş and Bebek.

In the study, Beşiktaş, Ortaköy, Kuruçeşme, Arnavutköy, Bebek and the areas between them are examined under individual headings and analysed in three stages: the situation before the 1939 plan, the 1939 plan and after.

The physical change of the region was tried to be determined by comparing the maps and aerial photographs. Firstly, information about the pre-1939 situation of the region was obtained from the old maps which the oldest one dated 1793. Some of the maps used in the work are involving the entire Bosphorus are undetailed and they are indicating whether there are settlements in the region or not. Some of them are detailed maps up to the parcel. After identifying the urban texture before 1939 by maps, what was foreseen to change in the 1939 plan was revealed. These were usually building blocks sizes, street types, street and avenue widths. It was then compared with the first map or aerial photograph available after 1939, to determine whether this proposal had been implemented until that date. It has been tried to determine whether the region has undergone any changes by comparing it with the later aerial photographs. With the aerial photographs that have survived until today, the change of the urban texture in time and its current
Figure 1. 1939 plan showing the settlements between Beşiktaş and Bebek and the coastal road. 
situation are also revealed. In short, the study questions the periods of changes in urban settlements.

From 1936 to 26 December 1950, Prost worked as an urbanism specialist at the Istanbul Municipality Development Directorate. He was dismissed by the Democratic Party, which won the local elections with a great victory after the 1950 general elections. Between 1950 and 1956, Turkish planners undertook the revision of the Prost Plan. Then, in 1956 Prime Minister Adnan Menderes personally directed the reconstruction of the city. In the following four years, until the military coup of May 27, 1960, intensive road construction, street widening, demolition of old buildings and construction of new ones continue (Akpınar, 2010), so an irreversible urban change took place in Istanbul. Afterwards, these demolitions continued in the period of Bedrettin Dalan between 1984 and 1989.

\section{ANALYSIS OF THE SETTLEMENTS BETWEEN BEŞIKTAŞ AND BEBEK, IN THE BOSPHORUS COASTAL ROAD PLAN DATED 1939}

Istanbul is a unique city with the Bosphorus that divides the city into two. For this reason, Bosphorus settlements also have a special importance. The settlements, which were the Bosphorus villages of the 1930s, are the favorite districts of Istanbul today. These settlements are included in general maps describing Istanbul or the Bosphorus or on more detailed maps drawn on the basis of regions (Figure 2).

Figure 2. Bosphorus villages in the current aerial photo and study area.

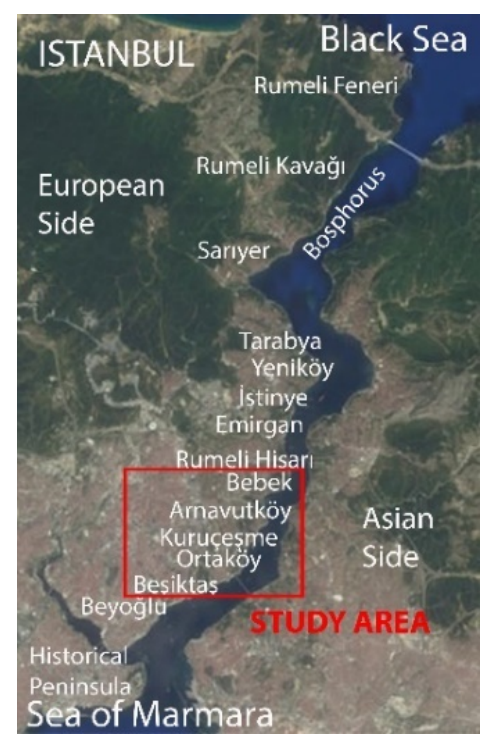

T. Mollo map dated 1793-1802 (Figure 3a), Benar Sampierdarena Oliver map dated 1800 (Figure 3b), M. Bourgoulou map dated 1803 (Figure 4a), 1894-95 dated map in Atatürk Library (Hrt_Gec_000006) (Figure 4b), Nedjib map dated 1918 (Figure 4c) and Mamboury map dated 1929 (Figure 5) are the general maps used in this study about Istanbul and Bosphorus. 

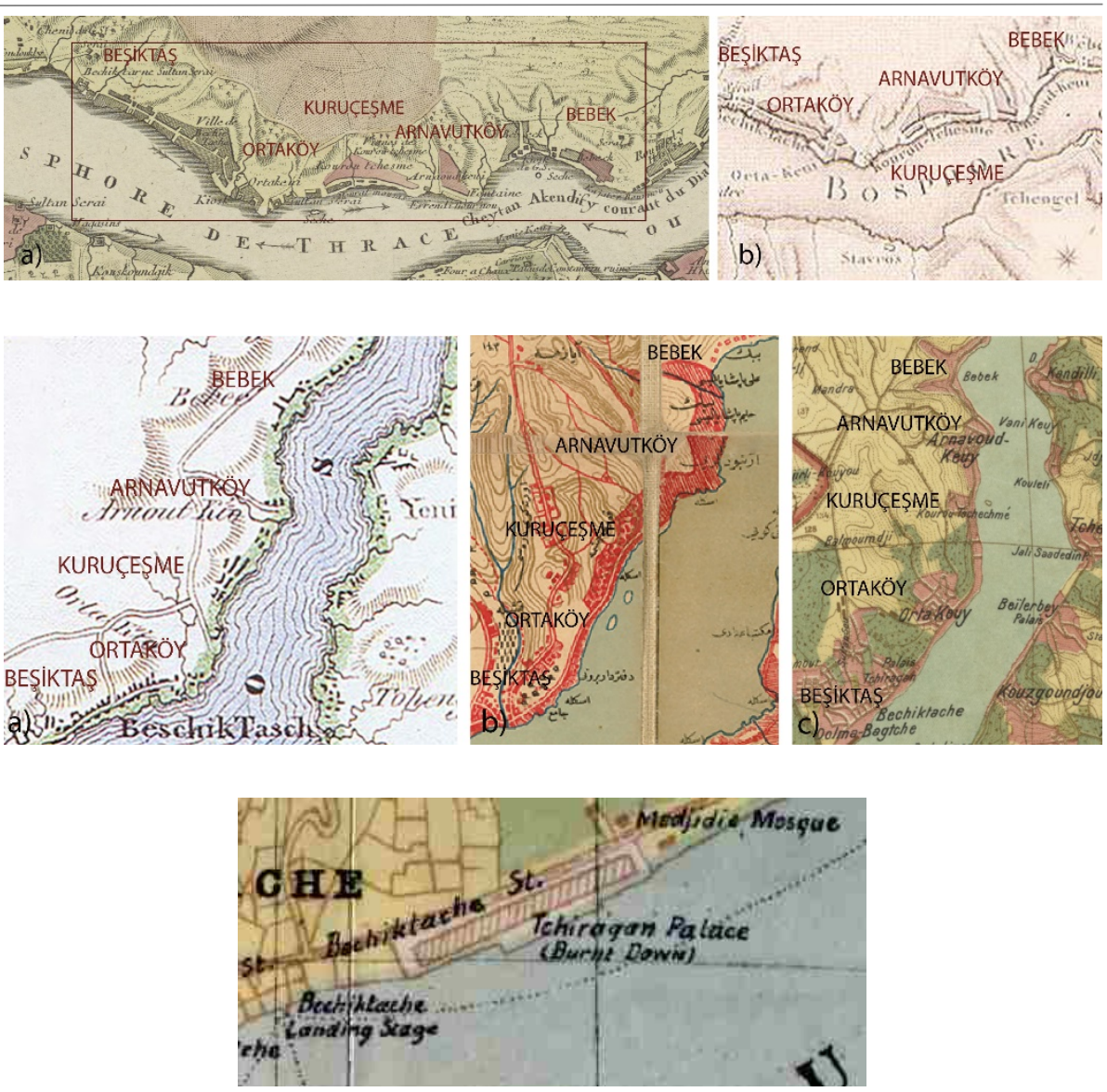

\section{Beşiktaş}

Beşiktaş having a deep-rooted history, has been included in many maps from past to present. In the Mollo map dated 1793-1802, the Sultan's Palace is the only structure took place in Beșiktaş (Figure 3a). Beșiktaş can be seen on the map of Dolmabahçe, which was prepared in 1834 in Mühendishane (Figure 6a). However, it was realized that the traces on the map did not coincide with the current traces on building blocks-road basis, and it was assumed that a precise drawing could not be made during this period (Gökyay, 2009). An important information learned from this map is the coastline trail. Compared to the current map, it is understood that the coast is quite filled. In the map dated 1882, Sinan Pasha Bath, Valide Mosque on the north of Beşiktaş Street and three docks on the coast can be seen. The coastline on this map is similar to that of 1834 (Figure 6b).

Althought Gökyay says 1894 Moltke map shows that the river in Beşiktaş reaches the Bosphorus (Figure 7a), in 1882 map the river can not be seen. This river dried up in the $19^{\text {th }}$ century and was filled during the construction of Akaretler (Gökyay, 2009). In the 1914 dated Alman Mavileri maps, streets and the monumental buildings is highlighted. The monumental buildings shown in this map are Sinan Pasha Mosque, tramway station, police station, the Barbaros Hayrettin Pasha Tomb, the Sinan Pasha Fountain, the Yedi-Sekiz Hasan Pasha Tomb, and the Beşiktaş Dock (Figure 7b). The 1918 Nedjib map includes the building
Figure 3.

a) 1793-1802 dated T. Mollo map

b) Benar Sampierdarena Oliver map, 1800's, (Atalan, 2015).

\section{Figure 4.}

a) 1803 dated M. Bourgoulou map (Atalan, 2015)

b) 1894-95 dated Istanbul and Bosphorus map, (Atatürk Library,

Hrt_Gec_000006)

c) 1918 dated Necip map.

Figure 5. 1929 dated Mamboury map. 
blocks, streets and their names, green areas and buildings (Figure 7c). The 1922 Jacques Pervititch map contains a lot of detail on a parcel basis and is the most detailed map used in the study (Figure 8a). According to this map, there are various docks and their buildings on the coast, including the Beșiktaş ferry dock. To the west of ferry dock, there is a material warehouse of Atlas company, its dock and one-storey wooden sheds, a firewood dock, a custom and a two-storey masonry building. To the east of the ferry dock there is a straw dock, sand storage, lime storages and wooden sheds. On Beşiktaş street, there are two storey shops, cinema, central police station, Municipality building, Barbaros Hayrettin Pasha and Yedi-Sekiz Hasan Pasha tombs. Towards Dolmabahçe Palace, on the coast there are wooden mansions and their docks, with their gardens at the back, horse stables, warehouses, there is a complex and adjacent structuring (Figure 8a). In the map of Rumeli Ciheti (2005), dated 1924, only the streets and monumental buildings are shown, as in the Alman Mavileri map. The street boundaries are the same as the Alman Mavileri map, but fewer monumental structures such as Sinan Pasha Mosque and Fountain and Barbaros Hayrettin Pasha Tomb are shown this map (Figure 8b).

Figure 6.

a) Beşiktaş in "Dolmabahçe and surroundings" map, prepared by Mühendishane (schools of engineers), 1834 (Çetintaş, 2005).

b) Istanbul map, 1882.

Figure 7. Beşiktaş in

a) Moltke map, 1894 (Çetintaş, 2005)

b) Alman Mavileri, 1914.

c) Necip map, 1918, (SALT

Online Archive, access code: APLNEDOT02A)

Figure 8. Beşiktaş in a) Jacques Pervititch map, 1922 (the notes on the aerial photos are written by the author).

b) Rumeli Ciheti map, 1924.
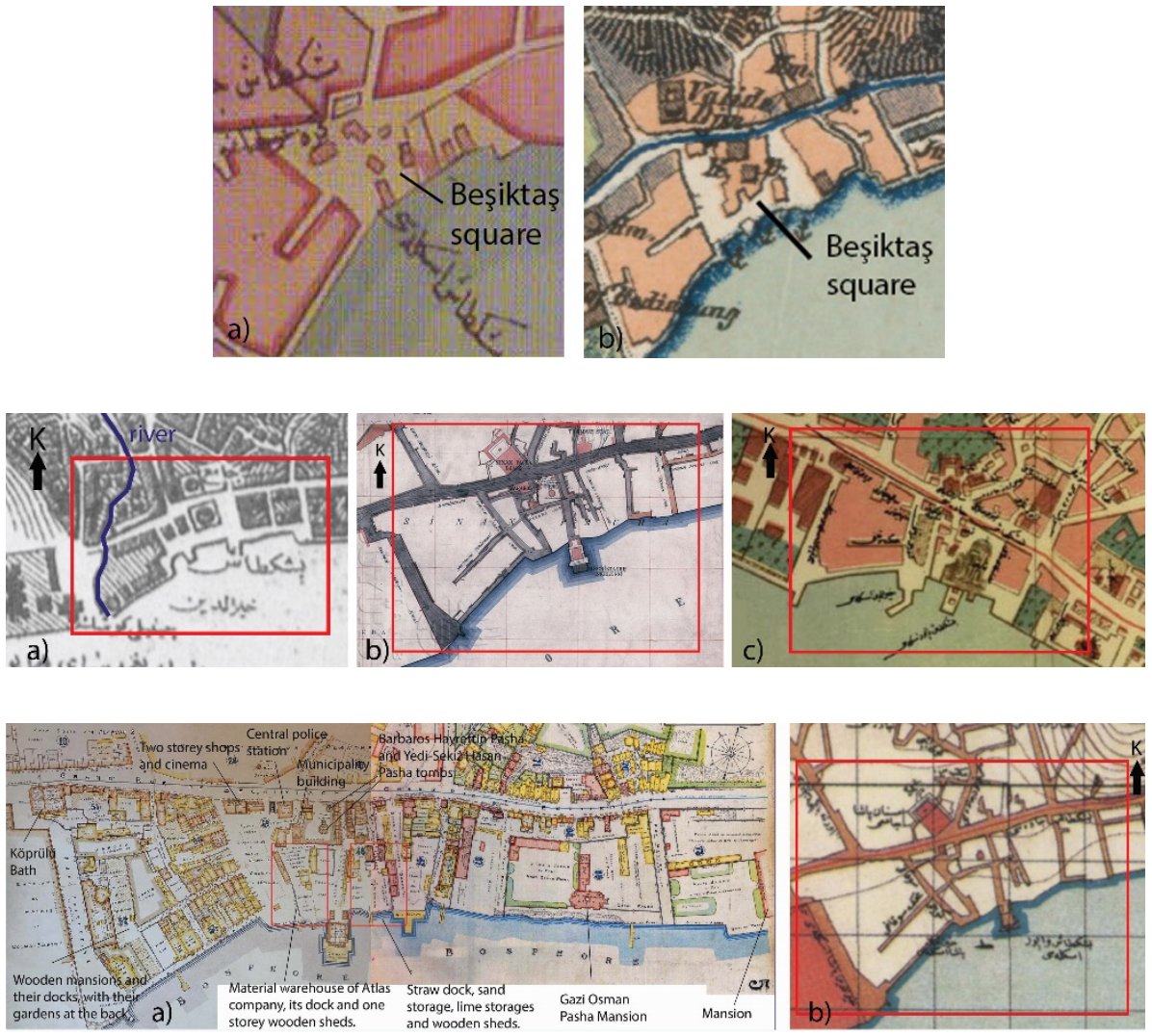

According to the map approved in 1939 where the change of centers on the coast was planned, the coastline is planned as a smooth line (Figure 9). To implement this, it has been proposed to increase the triple of Hayrettin Dock Street parallel to the coast and on the west of Beşiktaş Ferry Dock. Mahkeme dead end street, parallel to Hayrettin Dock Street, 
was transformed into a normal street and increased to approximately twice the width. The street, which is connected to the Beşiktaş Ferry Dock remains on the central axis, squares has been created in the east and west. In the west, the streets in the area where Barbaros Hayrettin Pasha's tomb is located and a few dead-end streets in the east have been removed. Streets at different angles in Beşiktaş are arranged perpendicular to the beach. Beşiktaş-Ortaköy Street (also known as Dolmabahçe Street and Beşiktaş Street) has been almost doubled to 25 meters, and it is planned to end with straight lines. In the north of this street, the organic textured streets around Sinan Pasha Mosque were removed and instead a new avenue as wide as a main street (today's Barbaros Boulevard) was planned to be opened. The Serencebey slope to the east of it also has been almost doubled. This zoning plan was approved in 1939, provided that the area within the ABCD was restudied (Figure 9). However, no plan was identified that those etude studies done.

Ünsal (1968) published a photo showing the just opened Beşiktaş square (Figure 10). The applied version of the regulations in the 1939 plan can be seen in this photo. However, the fact that the photo was dated in 1938 contradicts the 1939 approval date of the plan. It is thought that the date of photo is after 1939. In another photograph dated 1943, Beşiktaş square is seen again. (Figure 11).
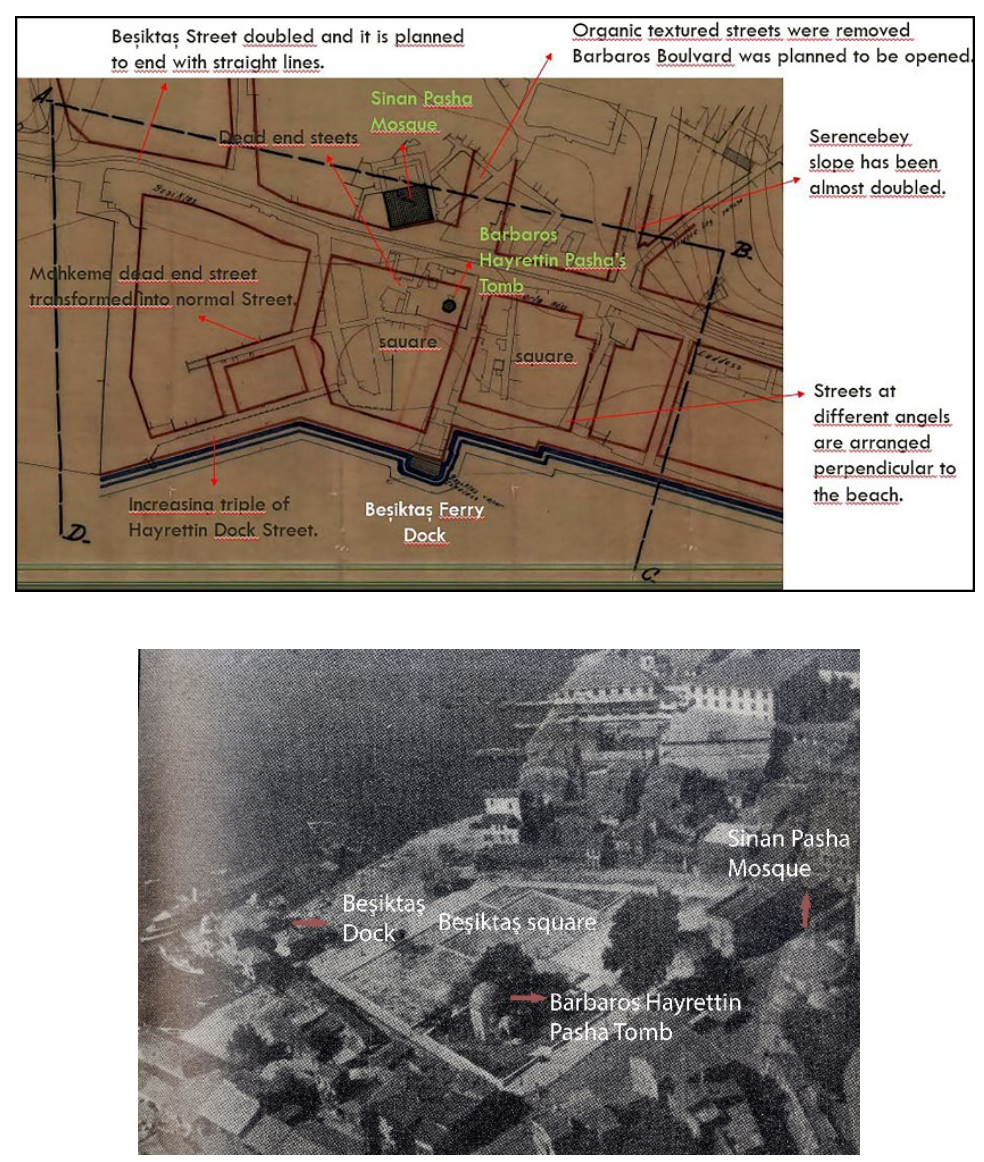

Figure 9. The plan of 1939 was approved on condition that the ABCD area should be re-studied (Atatürk Library, Hrt_006246) (the notes on the aerial photos are written by the author).
Figure 10. Just opened square in Beşiktaş, 1938 (Ünsal, 1968) (the notes on the aerial photos are written by the author). 
Figure 11. Beşiktaş Square in 1943 (Daver, Resmon and Günay, 1943).

Figure 12. 1940 dated Istanbul transportation system proposal by Prost, Bosphorus part.

Figure 13. Bülent Tuvalo map, 1955 (SALT Online Archive, access code: APLBTISTNDX01) (the notes on the aerial photos are written by the author).
Bosphorus Coastal Road and Settlements Between Beşiktaş and Bebek in 1939 Plan

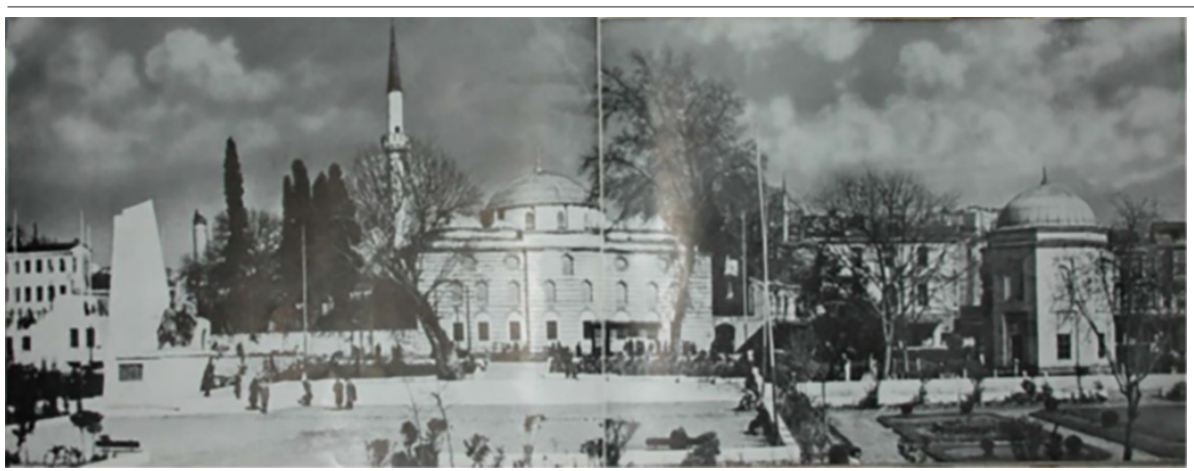

In Istanbul's transportation system proposal plan, which was prepared by Prost in 1940, the coastal road, Barbaros Boulevard and Beşiktaş square were marked in the Bosphorus region. This shows that the biggest change in the Bosphorus is foreseen in Beşiktaş (Figure 12).

The oldest map obtained after 1939, Bülent Tuvalo's 1955 map of Istanbul (Figure13) shows that the square was opened against Beşiktaş Ferry Dock while the other regions of Beşiktaş, the street texture has not changed.
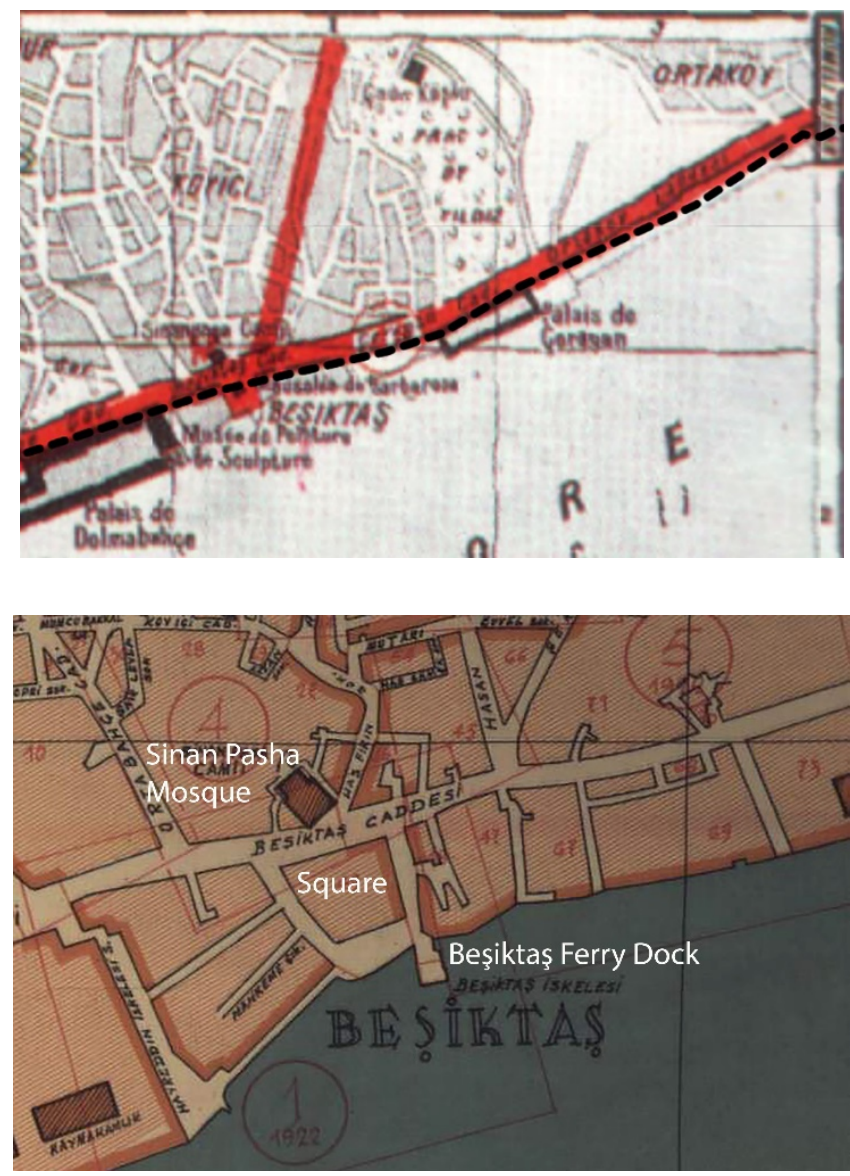

Beside the square, urban texture of Beşiktaş, changed considerably between the years 1956-1958 in the reconstruction arrangements of the Menderes period, and many historical buildings were destroyed in this process. In 1956, while Beşiktaş Avenue was enlarged, the bath, 
fountain, and clock room (Muvakkithane) of the Sinan Pasha Complex and Hacl Ahmed Ağa Fountain were also destroyed (Figure 14). The bath was built as a part of Sinan Pasha Complex, across the road, southwest of the mosque. The complex, dated 1555, was built by Mimar Sinan for Kaptan-ı Derya Sinan Pasha. The location of the bath was at the corner of Beşiktaş Street and Hayrettin Dock Street. Sinan Pasha Bath was also known as Köprübaşı Bath because it was located at the head of bridge which was on the Beşiktaş river dried in the late 19th century. It was built as a double bath (Kuban, 1994). Köprübașı Bath, which is one of the most beautiful examples of the classical period Ottoman baths in Istanbul, was demolished with the decision of "High Council of Monuments" with the thought it does not have any artistic value. The demolition of historical buildings has caused great damage to Beşiktaş's historical texture (Doğusan, 2004).

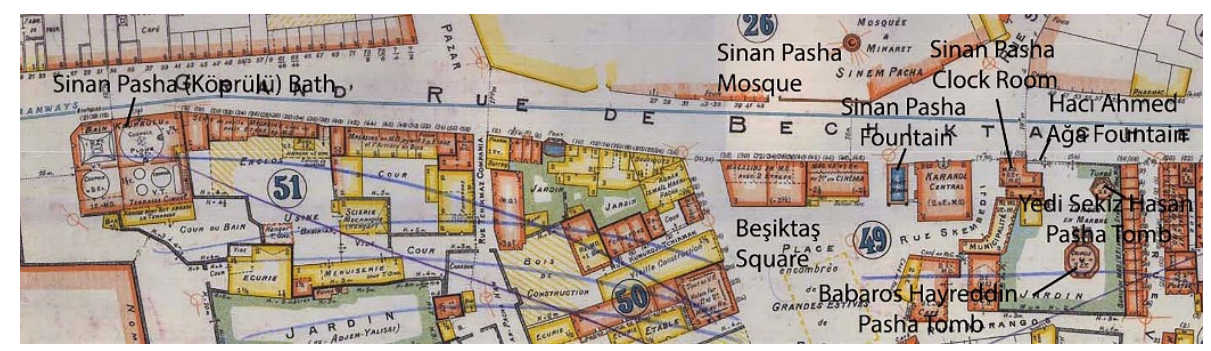

Within the scope of the reconstruction of the Menderes period, between 1956 and 1958, Barbaros Boulevard, which divides the settlement into two, ignores the existing texture and connects Beşiktaş to Zincirlikuyu, was opened and thus the neighborhood lost many cultural assets. Approximately 270 buildings were expropriated in order to open the 50 meters wide Barbaros Boulevard and this boulevard is also intended as the port on the European side of the Bosphorus Bridge in 1973. This boulevard is also intended as the junction point of the Bosphorus Bridge on the European side (Doğusan, 2004).

The changes made during the Menderes period can be seen in the 1966 aerial photo (Figure 15a). It is noteworthy that many of the arrangements in the 1939 plan were implemented during the Menderes period. In addition to Beşiktaş Street and Barbaros Boulevard, as suggested in 1939, the avenue descending to Beşiktaş Dock was enlarged and the area to the west of this avenue was arranged and Barbaros Hayrettin Pasha monument was added. During this process, the Governor's Office, tobacco warehouses on the coast and other warehouses and buildings were expropriated. However, as in the 1939 plan, the street in the west of the building block was not arranged perpendicular to the coast and the existing street contours were preserved. Mahkeme dead end street was completely abolished. The east of the street descending to the dock was destroyed in 1966 to create another square. In 1970 aerial photo, this region is also arranged. In 1982 aerial photo, a road was passed through the region and
Figure 14. Historical buildings in Beşiktaş on the Pervititch map (the notes on the map are written by the author). 
connected to Barbaros Boulevard (Figure 15b). Aerial photo of 2011 shows that the historical Tobacco Store on Hayrettin Street has been converted into a hotel.

Nowadays center of Beşiktaş is on the verge of a major transformation. With the Beşiktaş Square Project, which has been on the agenda since the 1990s, vehicle traffic is planned to be underground and the square is planned to be pedestrianized (Istanbul Metropolitan Municipality, 2020).

\section{Figure 15.}

a) 1966 aerial photo.

b) 1982 aerial photo (the notes on the aerial photos are written by the author).
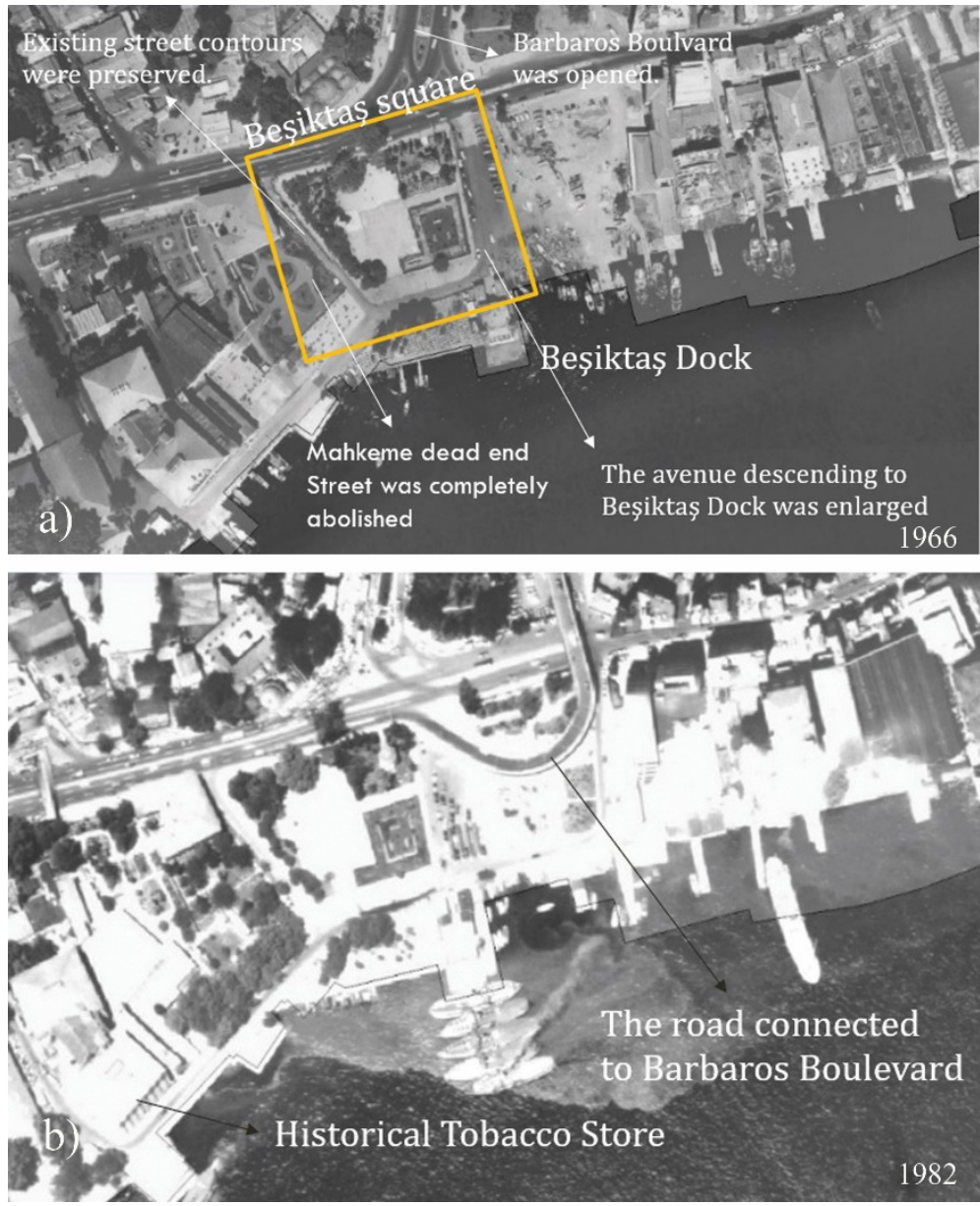

\section{The Area Between Beşiktaş and Ortaköy}

In old maps, seen structuring between Beşiktaş and Ortaköy since the $18^{\text {th }}$ century (Figure 3 ). The most mentioned of these structures is the Çirağan Palace (Figure 5, 12 and 16a). At the end of the 19th century, Feriye Palaces were located between Beşiktaş and Ortaköy squares. In addition to the palaces, mansions such as Gazi Osman Pasha Mansion were located here (Figure 16a). In 1927 Pervititch map, there were masonry coal depots and warehouses. Besides them there were Turkish girls' schools in the place of Kabataş Erkek High School today (Figure 16b). Beşiktaş Street, which passes behind the warehouses, consists of 15 and 10 meters streets at different elevations in the 1939 plan. Between these roads, which are separated as departure and arrival, the right and left trees are afforested (Figure 17). 

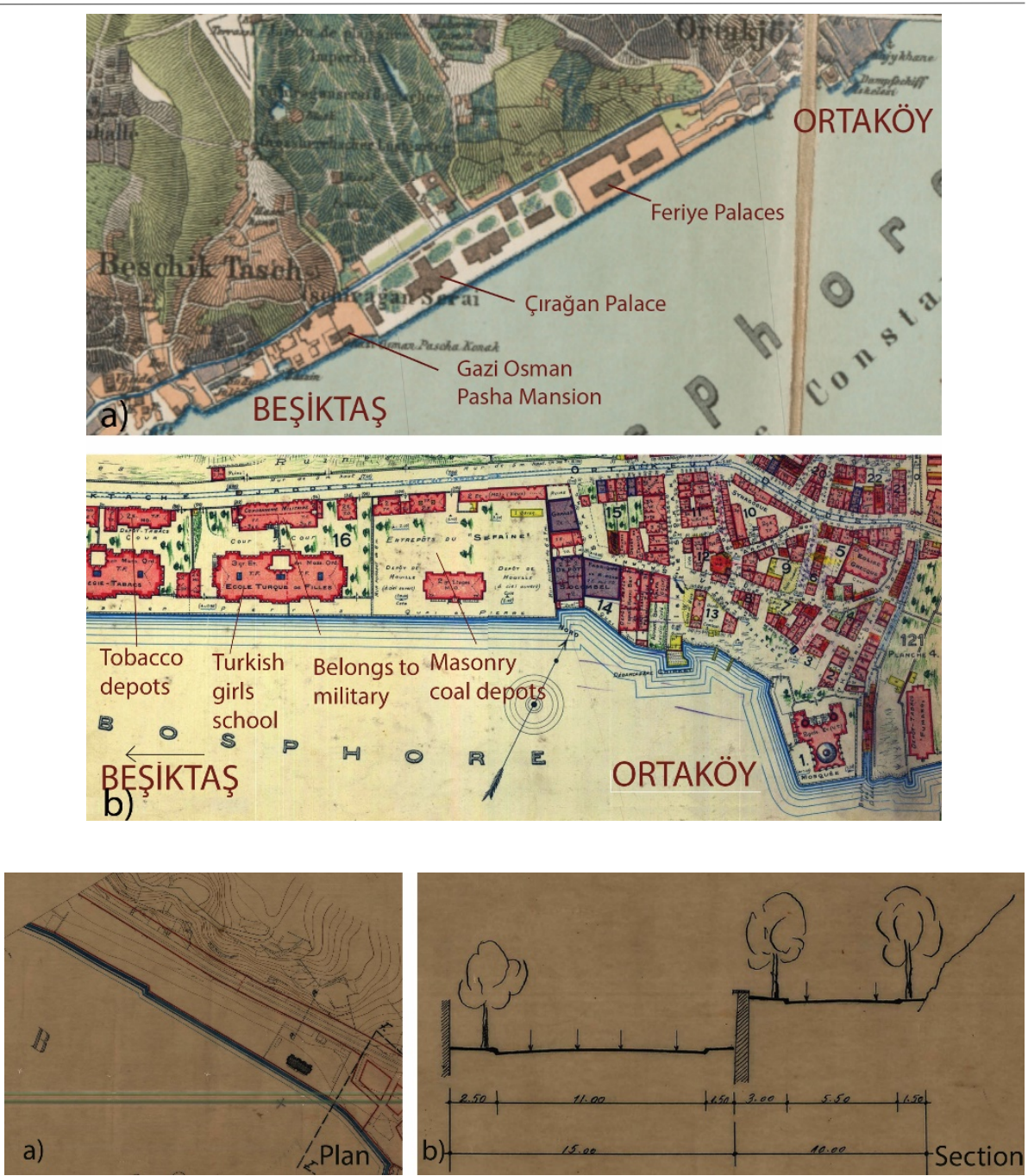

\section{Ortaköy}

In the general maps of the $18^{\text {th }}$ and $19^{\text {th }}$ centuries the most prominent structure is the Great Mecidiye Mosque (Ortaköy Mosque). Alman Mavileri maps (1914) (Figure 18a) shows only the streets and monumental buildings. Ortaköy Alman Mavileri map include dock, church, synagogue, many fountains, schools, and Ortaköy Mosque. The streets and monumental structures on the Plan d'Ensemble de la Ville de Constantinople (1922) (Figure 18b) are almost the same as the 1914 map. 1927 dated Pervititch map reveals that Dereboyu Street to the east of the mosque divides the city texture into two (Figure 19). While the west side of this street consists of smaller and adjacent buildings and smaller building blocks, there are larger and discrete ordered buildings with gardens in the east side.
Figure 16. The area between Beşiktaş and Ortaköy in a) 1882 map.

b) 1927 dated Pervititch map (the notes on the maps are written by the author).

Figure 17. In 1939 plan, the area between Beşiktaş and Ortaköy (on the left) and Beşiktaş Street section (on the right) (Atatürk Library, Hrt_006246). 
Figure 18. Ortaköy in

a) 1914 dated Alman Mavileri map (the notes on the map are written by the author)

b) 1922 dated Plan d'Ensemble de la Ville de Constantinople.

Figure 19. In Pervititch map, Dereboyu street dividing the city texture into two.

Figure 20. Ortaköy in

a) 1939 plan (Atatürk Library, Hrt_006246)

b) 1955 dated Bülent Tuvalo map (SALT Online Archive, access code: APLBTISTNDX01).
Bosphorus Coastal Road and Settlements Between Beşiktaş and Bebek in 1939 Plan
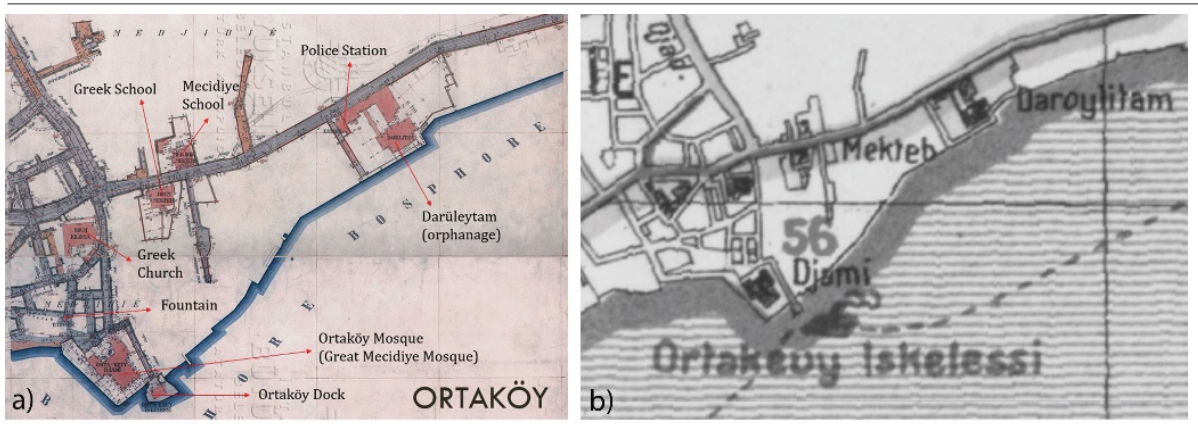

In the case of implementation of 1939 plan for this region, it is seen that many streets and building blocks and organic texture will be destroyed (Figure 20a). In this plan, Beşiktaş street widened to 25 metres. The new streets are planned parallel to the sea and wider. The small streets near the Ortaköy Mosque have been destroyed and the mosque is located in a larger area, increasing its visibility. As the street expands, a Greek church and school, a synagogue and a tobacco store on Ortaköy street were demolished. This plan was approved provided that the EFGH region was re-studied (Figure 20a). The dock on the beach is not available in the 1939 plan. The 1955 Istanbul map shows that these proposals are not implemented (Figure 20b).
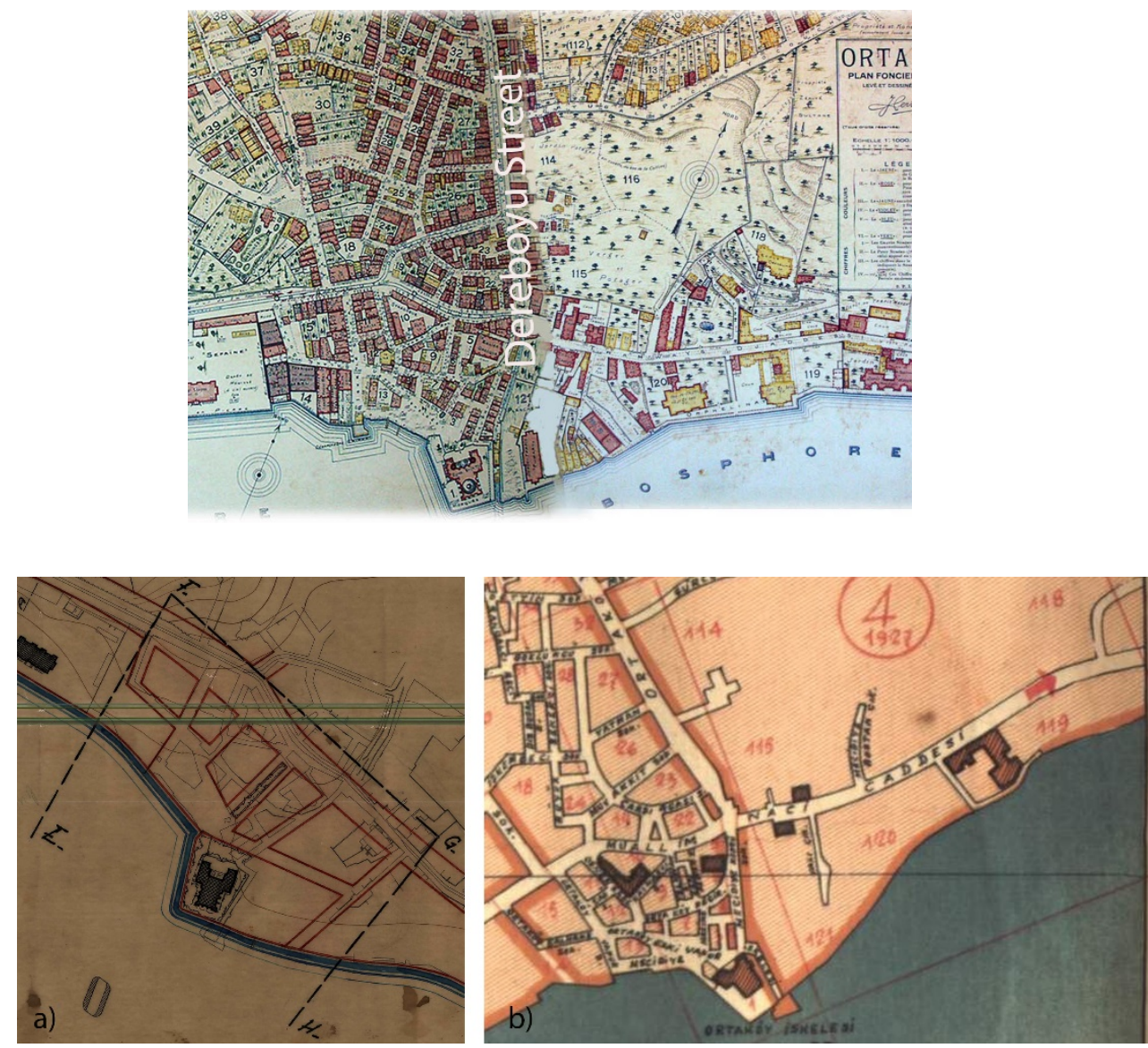

During the Menderes period, various arrangements were planned to be made around the Ortaköy Mosque, as suggested by the 1939 plan. The 
purpose of these arrangements is to ensure that the Ortaköy Mosque and Ortaköy Dock can be seen from the enlarged street (İstanbul'un kitabı, 1957).

However, since there are many buildings between the street and the mosque, this draft has not been implemented because of the demolition of these buildings will cost a lot. In the 1966 aerial photo it is detected that, the city texture around the Ortaköy Mosque is same as that seen on the Pervititch map (Figure 19). During this period, the coastal road in Ortaköy was enlarged by the demolition of the northern walls (Figure 21). After Ortaköy, the coastal road extending up to Sarıer has a width of 30 meters and casinos, entertainment places and beaches have been built along the road in order to gain a touristic appearance (İstanbul'un kitabı, 1957). As determined from the aerial photos, a small filling area was built in the southeast direction of Ortaköy Mosque between 1966 and 1970. This filling area still has its limits in 1970 (Figure 22). Today, Ortaköy preserves its old texture to a great extent.
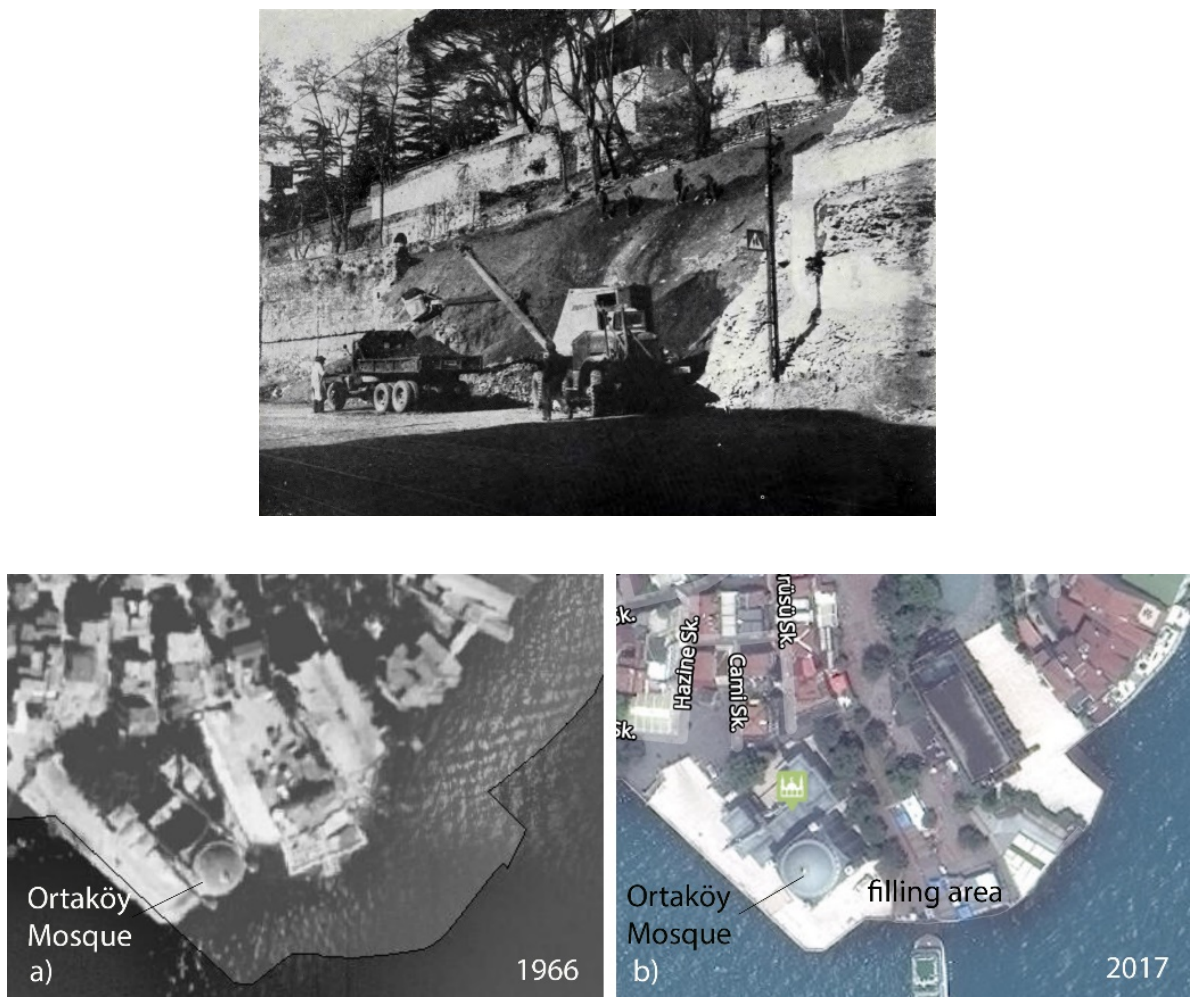

\section{The Area Between Ortaköy and Kuruçeşme}

The area between Ortaköy and Kuruçeşme has been home to mansions since the $17^{\text {th }}$ century. The coastal structure is seen in general maps from 1793 to 1918 (Figure 3 and 4). The map dated 1860-1870 includes the Saliha Sultan and Esma Sultan Palaces. By the passage of the tram road behind the mansions in 1907, their architectural compositions consisting of gardens, groves and pavilions were destroyed (Atalan, 2008). The 1914 Alman Mavileri maps does not show structures, but it can be seen how much the distance between the coast and the road
Figure 21. Ortaköy tram street widenings (İstanbul'un kitabı, 1957).

Figure 22. Ortaköy Büyük Mecidiye Mosque and filling area around it, in 1966 (on the left) and 2017 (on the right) aerial photos. 
Figure 23. The area between Ortaköy and Kuruçeşme in a) 1860-1870 dated Istanbul map

b) 1914 dated Alman Mavileri map.

Figure 24. The area between Ortaköy and Kuruçeşme in a) 1924 dated Rumeli Ciheti map

b) 1927 dated Pervititch map.
Bosphorus Coastal Road and Settlements Between Beşiktaş and Bebek in 1939 Plan

decreased from 1870 to 1914 (Figure 23). Again, on this map, there are orphanage (Darüleytam) and a police station near Ortaköy.

The buildings along the coastline which were the palaces and mansions belonging to the Ottoman dynasty and wealthy families, were burned, sold, demolished, and some of the lands were exposed.

It is seen that most of the buildings seen as "Sahilhane" in the 1920s were demolished and small sheds constructed instead, then they were used as coal depots in 1949s (Atalan, 2008). 1924 dated Rumeli Ciheti map shows coal depots on the coast (Figure 24a). On the 1927 dated Pervititch map, there are also tobacco stores close to Ortaköy (Figure 16b). In the 1936 development plan report, it was proposed to remove all the warehouses and industrial buildings in the Bosphorus. In the zoning plans, the groves and green areas in the Bosphorus were opened to low density housing. In the proposals made in 1943, it was stated that the coal depots in Kuruçeşme may remain in the same place (Atalan, 2008).
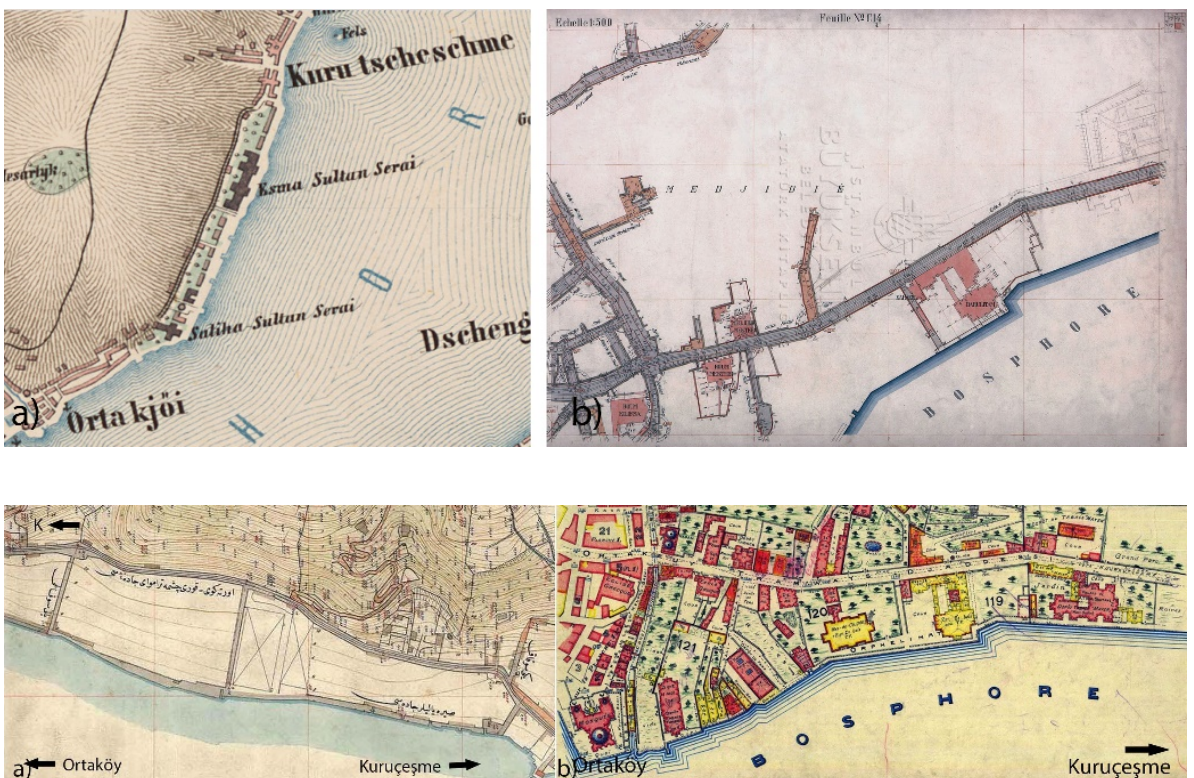

Beşiktaş Street (Ortaköy-Arnavutköy tram street) in 1939 plan is today Muallim Naci Street. To the east of Defterdar Mosque, there is "Sira Yalılar Avenue" close to the beach and "Yalı Street" connecting this avenue to the north (Figure 25). In the 1939 plan, a green coastline was established between Ortaköy and Kuruçeşme, including individual buildings. It is proposed that the coal depots close to Kuruçeşme will be demolished and turned into green areas. This plan was implemented in Menderes period. In 1956-58, the buildings on the coast between Kuruçeşme and Arnavutköy were completely removed and the continuation of the road was ensured. During this period, it was planned to transfer the loading and unloading facilities located on the coast between Lido Casino (the place of Reina which is closed until 2017) and Kuruçeşme and to evaluate the region as a tourism area. For this purpose, casinos, entertainment and bathing areas were planned and 
implemented. Kuruçeşme Island has been turned into a sports and camping area (İstanbul'un kitabı, 1957).

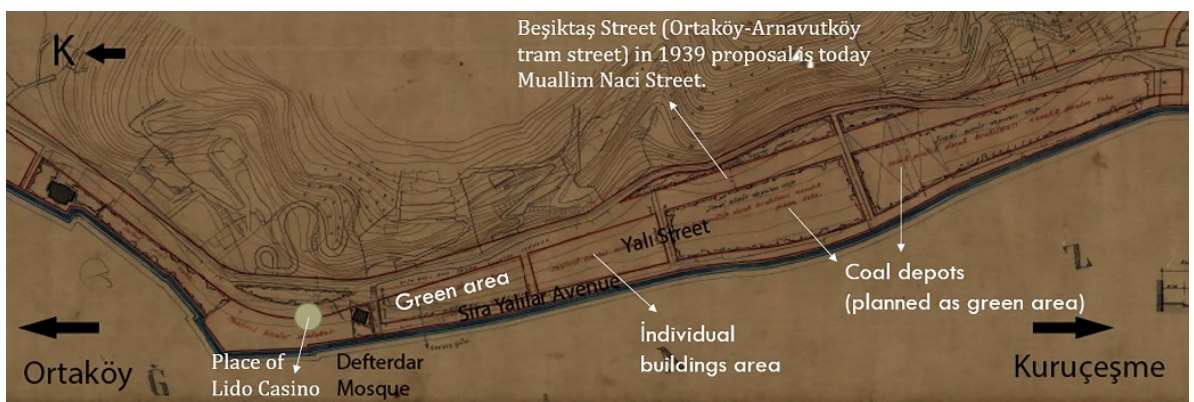

As seen from the aerial photos, while the building blocks on the west side of Kuruçeşme Square consisted of coal depots, parking areas and single buildings in 1982, in 2006 facilities such as hotels and restaurants were built on the north side of the island. Today, construction works continue in place of the collapsed coal depots. Fatma Sultan Mansion, which is seen on Pervititch map was demolished in 1960s and today there is the foot of the Bosphorus Bridge on its place (Figure 26).

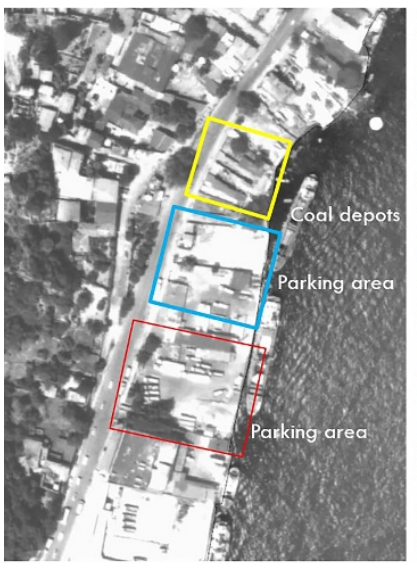

1982 aerial photo

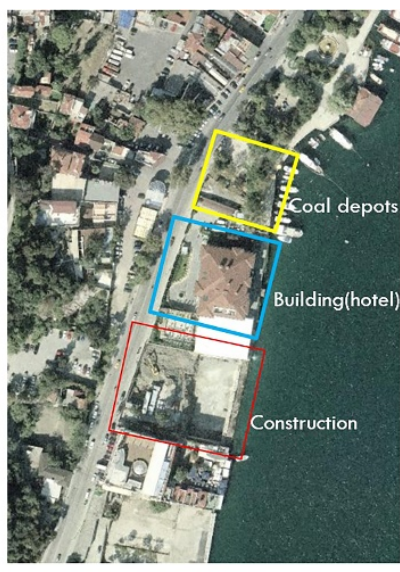

2006 aerial photo

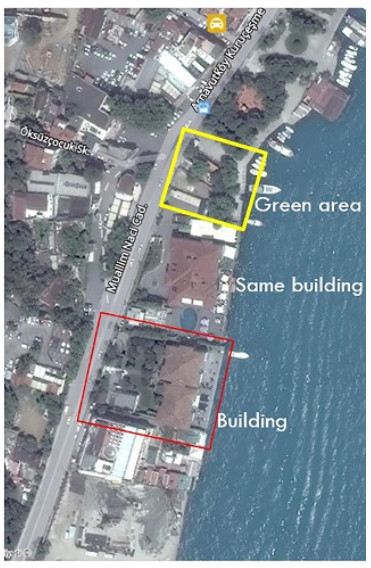

2017 aerial photo

\section{Kuruçeşme and The Area Between Kuruçeşme and Arnavutköy}

Kuruçeşme has taken its name from the waterless fountain next to the mosque built by Tezkireci Osman Efendi. After it was rebuilt by Köprülüzade Fazıl Ahmed Pasha's sister in 1682, it continued to use the same name. Another fountain was built here by Damat Ibrahim Pasha in 1728-29. Lots of mansions have been built in Kuruçeşme like Tırnakçı Mansion, Süreyya Pavilion, Esma Sultan (1763) and Atiye Sultan (1838) coastal palaces (Gökbilgin, 1992).

In the 1918 Nedjib maps, Kuruçeşme is seen as a smaller settlement with fewer structures compared to other settlements. The buildings in Kuruçeşme is seen in the old general maps (Figure 3) and the map of $1860-70$ (Figure 27). By 1860-70 map, in the 19th century there was only a few settlements in the region, and there are three islands in this axis in Bosphorus (Figure 27). The island opposite Kuruçeşme Dock is
Figure 25. The area between Ortaköy and Kuruçeşme in 1939 plan (the notes on the plan are written by the author).

Figure 26. 1982, 2006 and 2017 aerial photos of Kuruçeşme coastline (the notes on the aerial photos are written by the author). 
Figure 27. Kuruçeșme, Arnavutköy and the setllement between them in the years of 1860-70.
Figure 28. Kuruçeşme and the area between Kuruçeșme and Arnavutköy in the 1939 plan with its section (the notes on the aerial photos are written by the author).
Bosphorus Coastal Road and Settlements Between Beşiktaş and Bebek in 1939 Plan

Sarkis Bey Island, which is approximately $10.000 \mathrm{~m} 2$ in size. It was used as a coal depot in the 1900 s and later turned into a park (Gökbilgin, 1992).

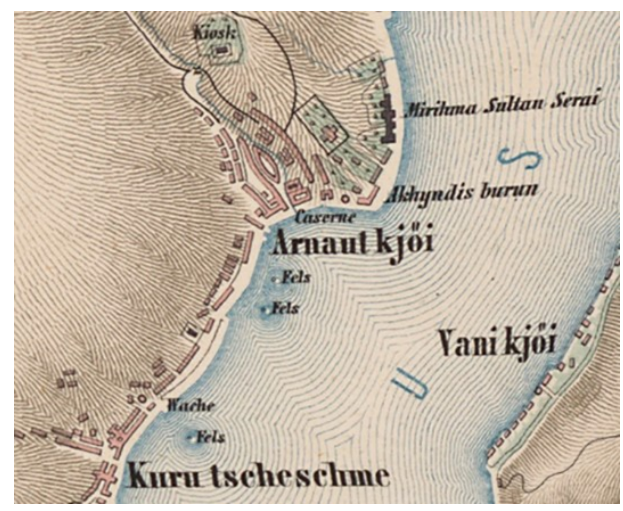

In the 1939 plan, Kuruçeşme is seen with a semi-circular square arrangement (Figure 28). It has been proposed that the existing Kuruçeşme Ferry Dock be rebuilt as bigger and a large area will be left as a square towards the dock. This proposal is quite different to the urban texture of Kuruçeşme consisting of organic streets. It has been suggested that the coal depots to the east of the Kuruçeşme Ferry Port will be demolished and the area will be left as a green area. The Kuruçeşme-Arnavutköy tram street is envisaged to be expanded to 25 meters as it is along the coast. This expansion is planned to be completed by filling the sea averagely 11 meters (Figure 28).

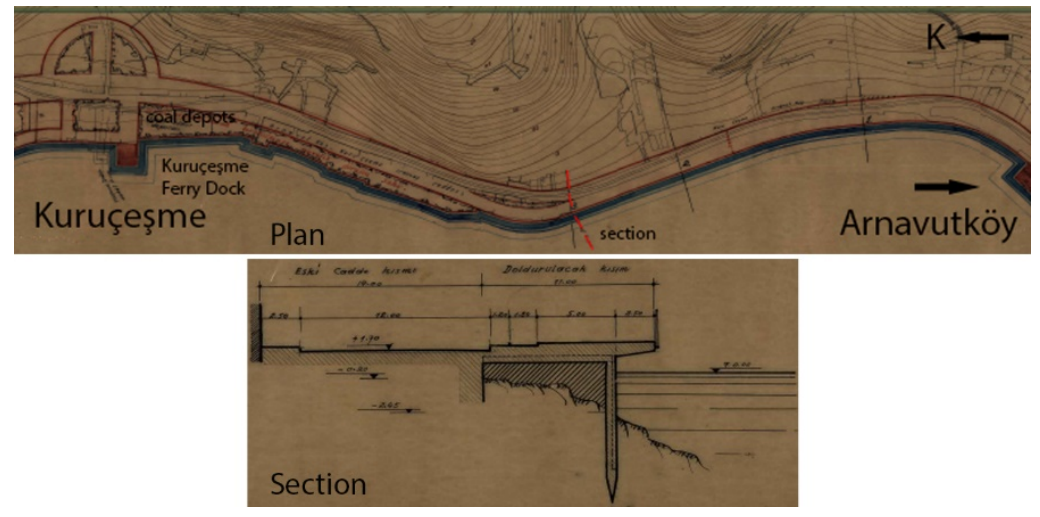

\section{Arnavutköy}

Arnavutköy, taking its name from the Albanians which are the first inhabitants of this region, was a very crowded village. Alongside the Albanians, Greeks and Jews also resided here and because not taking place Muslim people in the $17^{\text {th }}$ century, there was no Muslim religious structure in Arnavutköy till $19^{\text {th }}$ century.

In 1804, a fountain by III. Selim and between 1832 and 1833 Tevfikiye Mosque by II. Mahmud was built (Gökbilgin, 1992).

The map dated 1860-70 shows that the two rivers in Arnavutköy have reached the Bosphorus and the settlement started around these rivers. 
In $19^{\text {th }}$ century, the buildings were located in two different ways, located close to each other or seperately with their gardens (Figure 27).

As the maps of usually includes historical peninsula and end in Ortaköy, Arnavutköy region cannot be seen in many maps. The oldest map could be found in this study for this region is dated 1860-70. In this map, it is seen that settlement started around a river reaching the Bosphorus. While the buildings around the river are parallel to the river and close to each other, the buildings which are a little further away are within the garden. 1918 Nedjib map shows dock and structures on the coast (Figure 29a). 1918 dated Nedjib map shows dock and buildings on the beach. 1924 dated Rumeli Ciheti map is quite detailed. Tevfikiye Mosque on the coast, Taksiarsis Greek Orthodox Church and Greek school are the buildings that are seen on this map and still exist today. The urban texture is also very clear on this map. At this date, some of the settlements were grid and some were organic textured (Figure 29b).
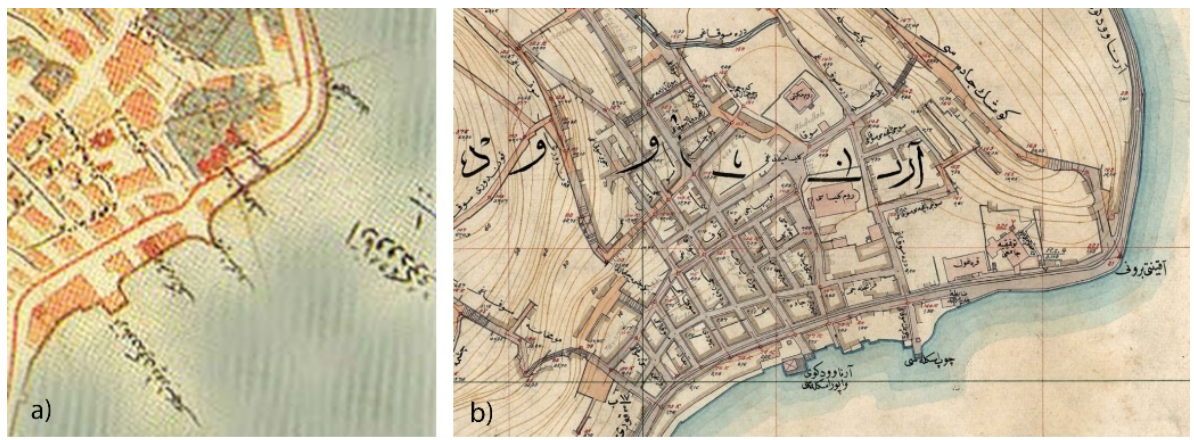

In 1939, two piers on the coast and green areas between them and three square-shaped building blocks in the west were proposed for this region. In addition, the widening of the tram street and the demolition of three building blocks during this process are among the suggestions. The Aya Dimitros Greek Church, which still exists today, was preserved in the 1939 plan. 1966 and 1970 aerial photos show that this plan was not applied (Figure 30).
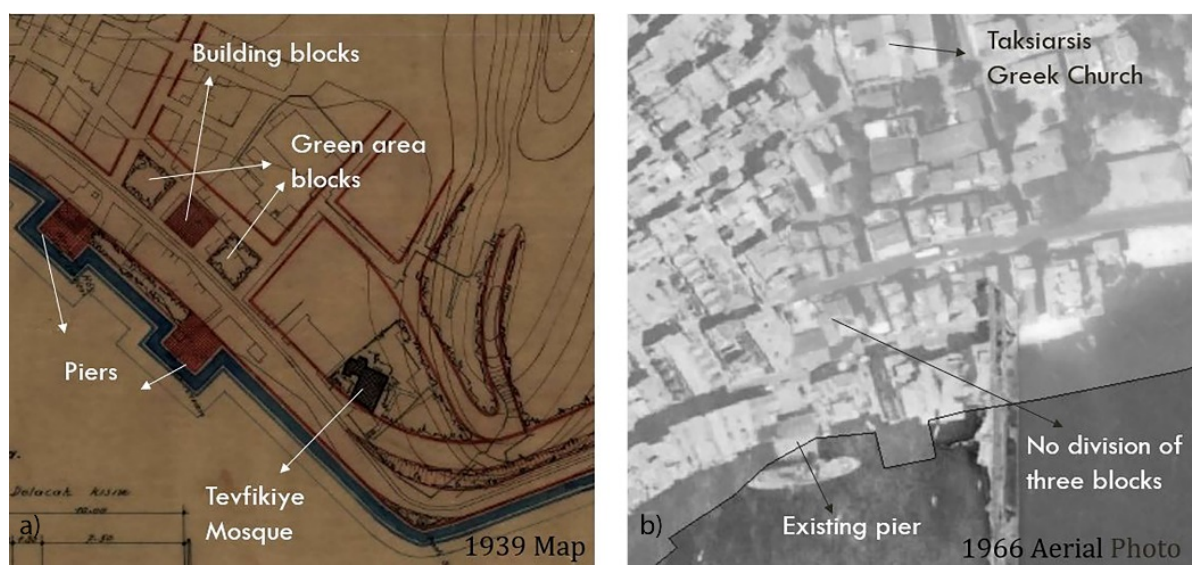

Figure 29. Arnavutköy in a) 1918 Necip map b) 1924 Rumeli Ciheti map.
Figure 30. Arnavutköy in a) 1939 plan

b) 1966 aerial photo (the notes on the plans are written by the author). 


\section{The Area Between Arnavutköy and Bebek}

In 1860 there are some buildings on the coast and a river between Arnavutköy and Bebek. Mihrimah Sultan Palace on the map dated 1860 and a few mansions close to Bebek have been destroyed and the buildings between Arnavutköy and Bebek cannot be seen in 1924 (Figure 31).

Figure 31. The area between Arnavutköy and Bebek in a) 1860-70 dated map b) 1924 Rumeli Ciheti map
Figure 32. The area between Arnavutköy and Bebek in the 1939 plan with its section (the notes on the aerial photos are written by the author).
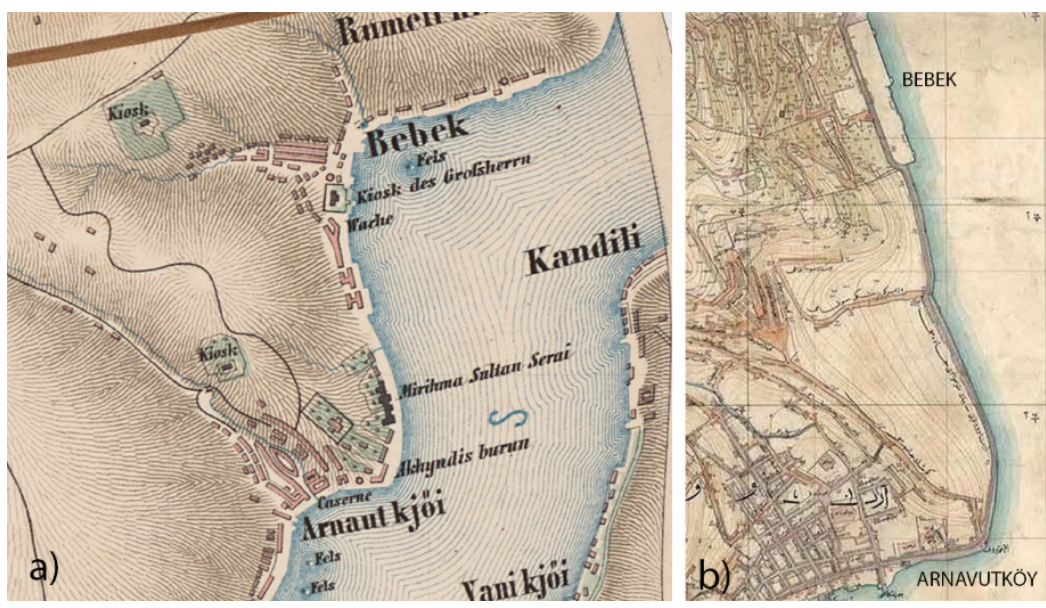

According to the plan of 1939 , it was proposed to expand the tram way in Arnavutköy (Figure 32). In Akıntıburnu, the solution was dividing the road into two and greening the middle of the two roads. It has been proposed that the coastal part of this road be expanded by filling the sea. The width of the road varies between 19.5-25 meters and the filling area ranges between 7.5-11 meters (Figure 32). During the reconstructions of Menderes period between 1956 and 1958, a large bund was built on the coast between the bend in Akıntıburnu and Bebek. By filling the coastal part of the road, the bund was formed and the old building of Boğaziçi High School, which coincides with this bund route, was destroyed and the surrounding area was enlarged (İstanbul'un kitabı, 1957) (Figure 33). In 1988, during the reign of Prime Minister Bedrettin Dalan, a new road was built by filling the sea in front of the mansions. The road, which was built on 720 steel piles, was built with a length of 1200 meters (Aksu, 2015) (Figure 34).

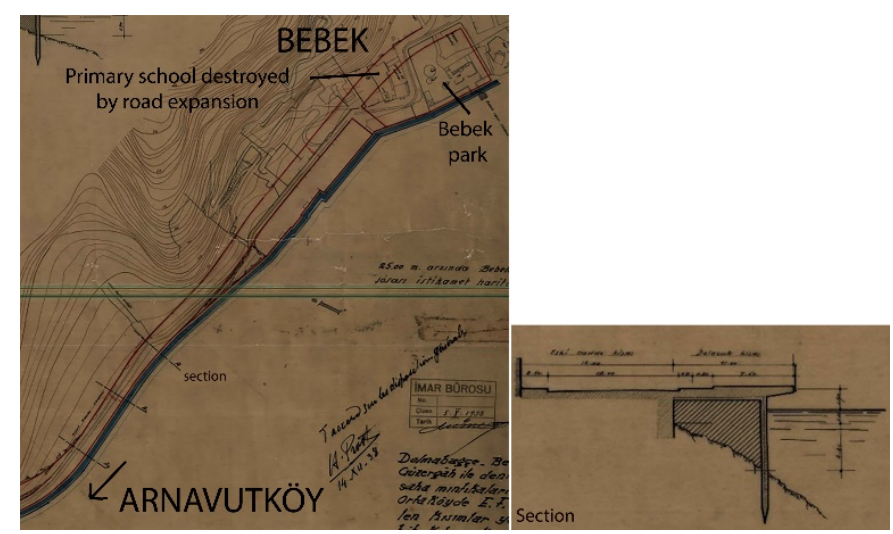



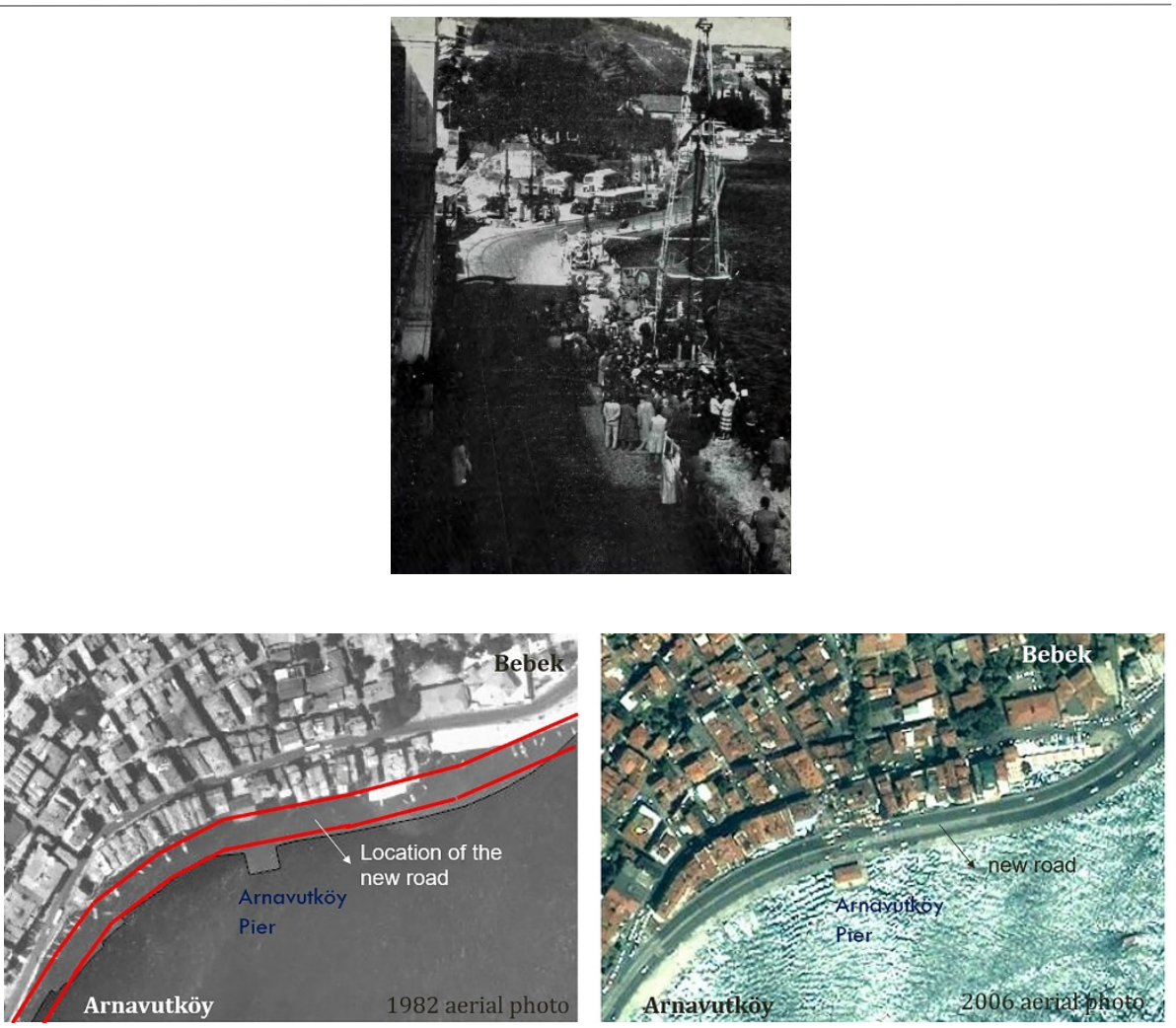

\section{Bebek}

Bebek was taken its name from Bebek Çelebi, who was responsible for this region during the Ottoman period and had vineyards and gardens in the region. The most important and oldest structure in the region was Yavuz Sultan Selim's Bebek Pavilion which was built in $16^{\text {th }}$ century. In $19^{\text {th }}$ century, pavilion demolished, and its area is being used as park of Bebek now. The Bebek Mosque, located to the east of the garden, was built in the $18^{\text {th }}$ century and later rebuilt by Architect Kemaleddin in the $20^{\text {th }}$ century (Gökbilgin, 1992). In 1860-70 map, the buildings in Büyük Bebek in the south are denser than Küçük Bebek in the north. And there are mansions and the sea bath on the beach.

Nedjib map dated 1918 shows Prince Halim Pasha Mansion and Valide Hidiv Pavilion on Bebek coast (Figure 35). The mansion of Halim Pasha was demolished by giving it to a destructor between 1930-1935 (Koçu, 1961). Valide Hıdiv Pavilion is currently used as Egyptian Consulate.

In 1939, it was proposed that the tram way in Bebek should be enlarged to 25 meters, while the primary school, another building and Bebek casino should be demolished, and surroundings of casino should be arranged as a green area (Figure 32).
Figure 33. Removal of structures and widening of the road in Arnavutköy, Akıntıburnu (İstanbul'un kitabı, 1957).

Figure 34. The road built by filling the coast is seen in 2006 (on the right) when it was not seen in 1982 aerial photo (on the left) (the notes on the aerial photos are written by the author). 
Figure 35. Bebek coast in 1918 dated Necip map.

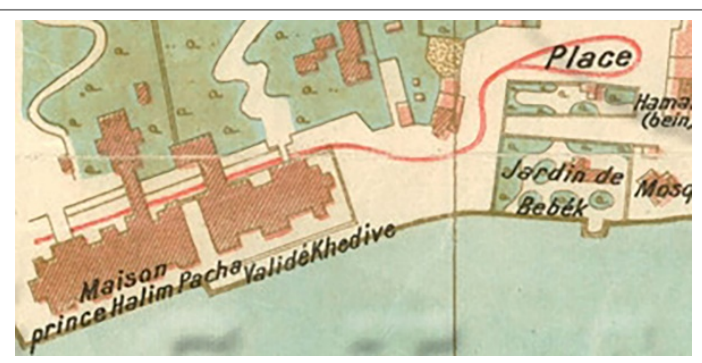

\section{FINDINGS AND THE CONCLUSION}

The following conclusions have been reached in the study, which examines the 1939 plan decisions drawn for the planning of the coastal road between Beşiktaş and Bebek and the settlements there and questions the periods in which this plan was implemented and how the urban identities of the regions were affected by this application.

While making plan decisions;

- Settlement centers and squares were opened to make them more visible.

- Streets were widened, including the coastal road over which the tram passes, and dead-end streets turned into streets. However, during this process, the integrity of the building blocks was disrupted, some monumental buildings were destroyed, and some were tried to be preserved.

- With the coastal arrangements, it is aimed that the coastal line will have a smooth line.

- It is suggested that the coastal line be cleared of warehouses and lowrise buildings and turned into a green area.

It is noteworthy that these decisions are the decisions Prost takes into consideration in all of its planning (Daver, Resmon and Günay, 1943).

Most of what was drawn in the plan was implemented, some of it was not. When classified according to the implementation periods, it is seen that the plan is implemented in the periods below;

- $\quad$ During the Prost period, who worked as an urban planning specialist at the Istanbul Municipality Zoning Directorate between 19361950, when Lütfi Kırdar was the prime minister.

- During the period of Prime Minister Adnan Menderes between 1956-1958.

- During the period of Prime Minister Bedrettin Dalan between 1984-1989.

The continuation of the implementation of the Prost plans during the Menderes and Dalan periods is also seen in the plans in other regions of Istanbul (Tekeli, 1993).

When it was questioned which practices were used in which settlements periodically within the framework of the 1939 Plan and how these affected the originality of the settlements, the following conclusions were reached: 
During the Prost period;

- The arrangements specified in the plan have been implemented for Beşiktaş Square. In this process, the dead-end streets were removed, the streets were expanded, storages, wooden sheds and warehouses were demolished.

During the Menderes period;

- $\quad$ The coastal road was widened from land or sea fronts, and the sea was filled in places. Ortaköy and Arnavutköy-Akıntıburnu are the places where the coastal road is mostly intervened. During this period, many historical buildings were destroyed.

- In Beşiktaş, Barbaros Boulevard was opened, and the street leading to Beşiktaş Street, Serencebey Slope and Beşiktaş Pier was expanded. During this period, important historical buildings such as the bath and fountain of Sinan Pasha complex were also destroyed. With these interventions, Beşiktaş is the settlement that has suffered the greatest damage both in terms of urban texture and ancient artifacts. The changes in Beşiktaş, which is a business center located at the intersection of Istanbul's busy streets, continue today.

- The loading and unloading facilities on the coast between Kuruçeşme and Arnavutköy were removed and entertainment venues were built instead.

- In Bebek, due to the extension of the coastal road, a part of Bebek Park, which has existed as the garden of Bebek Pavilion since the Ottoman period, and the baby casino, which is one of the important structures of the republic period, have been demolished.

During the Dalan period;

- The road between Arnavutköy and Akıntıburnu was built by filling the coast and driving piles. In this process, the relationship of Arnavutköy mansions with the sea was damaged, and the architectural identity of the mansions was also damaged.

- In Ortaköy, Kuruçeşme and Arnavutköy city centers, no implementation has been made in line with the plan. It is known that during the Menderes period, planning in Ortaköy was not implemented because it would cause high costs (İstanbul'un kitabl, 1957). Since Ortaköy was not intervened in line with the plan, compared to other settlements, it preserved its old texture and works.

It can be said that the plan of 1939 played a major role in making the Bosphorus coastal road and its surrounding settlements become today. So much so that although this plan was approved in 1939, most of the changes foreseen in this plan were implemented in the Menderes period and continued to be implemented in the Dalan period in 1988. This plan includes one of the first applications of sea fillings, which are being done quite often today.

With the findings obtained, it has been determined that this plan has many similarities with the conception of planning that Prost has 
adopted in other regions of Istanbul. Although Prost did not draw the 1939 plan, he approved it, and perhaps made the plan decisions himself. Considering that there may be other documents such as this document, which has not been handled in publications related to Prost because it was not drawn by Prost, it is understood that his contribution to the planning of Istanbul is more than known. Prost also supported the planning of Istanbul with plans such as the 1939 plan, which he guided to design.

\section{FINANCIAL DISCLOSURE}

The author declared that this study has received no financial support.

\section{ETHICS COMMITTEE APPROVAL}

Ethics committee approval was not required for this article.

\section{LEGAL PUBLIC/PRIVATE PERMISSIONS}

In this research, the necessary permissions were obtained from the relevant participants (individuals, institutions, and organizations) during the survey and in-depth interviews.

\section{REFERENCES}

Akpınar, İ. Y. (2014). The rebuilding of Istanbul: The role of foreign experts in the urban modernisation in the early republican years. New $\begin{array}{llll}\text { Perspectives on Turkey, 50, } & \text { 50. }\end{array}$ https://doi.org/10.1017/S0896634600006580

Akpınar, İ. Y. (2010). İstanbul'u (yeniden) inşa etmek: 1937 Henri Prost planı. In E. Ergut \& B. İmamoğlu (Eds.), 2000'den kesitler II: Cumhuriyet'in Mekanları/Zamanları/Insanları, Doktora Araştırmaları sempozyuтu (pp. 107-124). Dipnot Yayınları ve ODTÜ Yayınevi.

Aksu, F. (2015, August 8). 'Boğaz'ımıza kadar doluyoruz. https://www.hurriyet.com.tr/gundem/bogazimiza-kadar-doluyoruz29757923

Alman Mavileri 1913-1914. 1. Dünya Savaşı Öncesi İstanbul Haritaları (Vol. 1). (2006). İstanbul Büyükșehir Belediyesi Kütüphane ve Müzeler Müdürlüğü.

Ansel. E. (2016). Continuity and change on the Bosphorus shore: Arnavutköy before and after the Greek Revolution of 1821 [Master's Thesis]. Boğaziçi Üniversitesi.

Atalan, Ö. (2008). Boğaziçi kıyı yerleșmelerinin tarihsel değişim süreci ve koruma yöntemleri üzerine bir araștırma; Ortaköy-Kuruçeșme sahili [Ph.D. Thesis]. Yıldız Technical University.

Atalan, Ö. (2015). Rekonstrüksiyon Uygulamalarına Yönelik Kriterler Ortaköy- Kuruçeşme Sahili Örneği. Journal of Turkish Studies, 10(6), 227-246. https://doi.org/10.7827/TurkishStudies.8087

Aysu, Ç. (1989). Boğaziçi'nde Mekansal Değişim [Ph.D. Thesis]. İstanbul University. 
Beşiktaş_Bebek-Dolmabahçe arası istikamet haritasıdır (Hrt_006246). (1938). [Plan]. İstanbul: İmar Bürosu; Haritalar Arşivi. http://ataturkkitapligi.ibb.gov.tr/

Beydilli, K. (2005). Moltke, Helmut von. In Türkiye Diyanet Vakfı İslam Ansiklopedisi (Vol. 30, pp. 267-268). Türkiye Diyanet Vakfı Yayınevi.

Bilsel, F. C. (2010). "Henri Prost's" Planning Works in Istanbul (19361951): Transforming the Structure of a City through Master Plans and Urban Operations (P. Pinon \& F. C. Bilsel, Eds.). Suna ve İnan Kıraç Vakfı İstanbul Araştırmaları Enstitüsü.

Bilsel, F., \& Zelef, H. (2011). Mega Events in Istanbul from Henri Prost's master plan of 1937 to the twenty-first-century Olympic bids. 26, 621634. https://doi.org/10.1080/02665433.2011.599931

Cansever, T. (1994). Ev ve Şehir. İnsan Yayınları.

Coşkun, H. (2017). 20. Yüzyılın ilk yarısında konut sorununun ele alınış yöntemleri ve Henri Prost İstanbul örneği [Ph.D. Thesis]. Mimar Sinan Fine Arts University.

Coşkun, H., \& Doğrusöz, U. (2017). 20. Yüzyılın Başlarında İstanbul Tarihi Yarımada'da Henri Prost Dönemi Planlamaları; Prost Sonrası 1950'lerden İtibaren Kentin Morfolojik Dönüşümü. "DeğişKent" Değișen Kent, Mekân ve Biçim Türkiye Kentsel Morfoloji Araştırma Ağı II. Kentsel Morfoloji Sempozyumu, 579-586.

Çelik, Z. (2015). 19. Yüzyıl Osmanlı Başkenti: İstanbul. Tarih Vakfı Yurt Yayınları.

Çetintaş, M. B. (2005). Dolmabahçe'den Nişantaşı'na: Sultanların ve Paşaların Semtlerinin Tarihi. Antik A.Ş. Kültür Yayınları.

Daver, A., Resmon, M. N., \& Günay, S. (1943). Güzelleşen İstanbul. İstanbul Maarif Matbaası.

Diker, N., Dinçer, İ., \& Enlil, Z. (2008). Conservation of Bosphorus' spirit in spite of the spatial conflicts and threats. 16th ICOMOS General Assembly and International Symposium: 'Finding the Spirit of Place between the Tangible and the Intangible.' Quebec, Canada. https://www.icomos.org/quebec2008/cd/toindex/77_pdf/77-8v98152.pdf

Doğusan, G. N. (2004). İstanbul "imar"ı: 1956-1960 [Master's Thesis]. İstanbul Technical Univesity.

Enlil, Z. M. (2011). The Neoliberal Agenda and the Changing Urban Form of Istanbul. International Planning Studies, 16(1), 5-25. https://doi.org/10.1080/13563475.2011.552475

Erdener, O. (1994). Boğaziçi Sahilhaneleri. İBB Kültür İşleri Dairesi Başkanlığı Yayınları.

Ergen, B. (2005). Boğaziçi Doğal ve Kültürel Sit Alanının Korunamamasında Planlama Faktörünün Büyükdere Örneğinde İncelenmesi. Korunan Doğal Alanlar Sempozyumu, 6, 313-318.

Gökbilgin, T. (1992). Boğaziçi. In Türkiye Diyanet Vakfı İslam Ansiklopedisi (pp. 251-262). https://islamansiklopedisi.org.tr/bogazici 
Bosphorus Coastal Road and Settlements Between Beşiktaş and Bebek in 1939 Plan

Gökyay, D. (2009). Beşiktaş Köyiçi Kentsel Sit Alanının 20. yy başından günümüze değişimi ve korunması için öneriler [Master's Thesis].

Gül, M. (2013). Modern İstanbul'un Doğuşu: Bir Kentin Dönüşümü ve Modernizasyonu. Sel Yayıncılık.

Gül, M. M., \& Lamb, R. (2004). Urban Planning in Istanbul in the Early Republican Period: Henri Prost's Role in Tensions among Beautification, Modernisation and Peasantist Ideology. Architectural Theory Review, 9(1), 59-81. https://doi.org/10.1080/13264820409478507

Güngör, N. (1999). Boğaziçi Büyüsü. İnkılap Kitabevi.

Gökbilgin, T. (1992). Boğaziçi. In Türkiye Diyanet Vakfi İslam Ansiklopedisi (pp. 251-262). https://islamansiklopedisi.org.tr/bogazici

İstanbul Rumeli Ciheti Haritaları. (2000). İstanbul Büyükşehir Belediyesi Kütüphane ve Müzeler Müdürlüğü.

İstanbul'un kitabı. (1957). İstanbul Vilayeti Neşriyat ve Turizm Yayınları.

Kentsel Dönüşüm ve Meydanlar. (n.d.). Retrieved December 11, 2020, from http://www.ibb.gov.tr/trtr/documents/kentseldonusumvemeydanlar/meydan/besiktas/besikta s.htm

Koçu, R. E. (1961). Bebek'de Ali Paşa Yalısı. In Dünden Bugüne İstanbul Ansiklopedisi (Vol. 5, p. 2334). Reşat Ekrem Koçu ve Mehmet Ali Akbay İstanbul Ansiklopedisi ve Neşriyat Kolektif Şirketi.

Kuban, D. (1994). Sinan Paşa külliyesi. In Dünden Bugüne İstanbul Ansiklopedisi (Vol. 7, pp. 2-4). Kültür Bakanlığı ve Tarih Vakfı Ortak Yayını.

Kuban, D. (1996). İstanbul bir kent tarihi Bizantion, Konstantinopolis, İstanbul, Türkiye İş Bankası Kültür Yayınları.

Mamboury, E. (1929). Guide constantinople (APLMAM03) [Map]. SALT Online Archive.

https://archives.saltresearch.org/handle/123456789/93750

Metin, A. B. (2010). Beşiktaşııın kentsel tarihi ve barındırdı̆̆ı mimari eserler [Master's Thesis]. Mimar Sinan Fine Arts University.

Mollo, T. (1793). Plan de Constantinople et du Bosphore [Map]. https://upload.wikimedia.org/wikipedia/commons/c/cd/Plan_De_Cons tantinople_et_Du_Bosphore.jpg

Nedjib, Ş. H. M. (1918). İstanbul rehberi. Heyeti Umumiye. Sekizinci Pafta (APLNEDOT02A) [Plan]. Hozel Matbaası; SALT Online Archive. https://archives.saltresearch.org/handle/123456789/97344

Özsoydan, G. (2007). Kentsel korumaya stratejik yaklaşım (Beşiktaş köyiçi kentsel sit alanı örneği) [Master's Thesis]. Mimar Sinan Fine Arts University.

Pervititch, J. (1922). Plan cadastral d'assurances. Béchiktache. No: 5. (APLPEBECH05) [Plan]. SALT Online Archive. https://archives.saltresearch.org/handle/123456789/105066

Pervititch, J. (1927). Plan cadastral d'assurances. Ortakeuy.(APLPEORTA01) [Plan]. SALT Online Archive. https://archives.saltresearch.org/handle/123456789/124841 
Plan d'Ensemble de la Ville de Constantinople. (1922). [Plan]. Société Anonyme Ottomane D'études et D'entreprises Urbaines; Princeton University Library. https://upload.wikimedia.org/wikipedia/commons/3/35/Istanbul_PU8 89.jpg

Prost, H. (1938). İstanbul'un nazım planını izah eden rapor, İstanbul Belediye Matbaası.

Prost, H. (1940). Prost transportation study [Map]. http://www.istanbulurbandatabase.com/

Salman, Y. (2004). Boğaziçi tarihi sit alanının yok olma süreci ve kalan sınırlı değerlerin korunma olasılıkları [Ph.D. Thesis]. İstanbul Technical Univesity.

Salman, Y., \& Kuban D. (2006). Boğaziçi Tarihi Sit Alanının Yokoluş süreci. İTÜ Journal A, 5(1), 104-114.

Suher, H. (1993). Planlama. In Dünden Bugüne İstanbul Ansiklopedisi (Vol. 6, pp. 265-275). Kültür Bakanlığı ve Tarih Vakfı Ortak Yayını.

Tekeli, İ. (1993). İcabında plan. İstanbul Dergisi, 4, 26-37.

Tekeli, İ. (2009). Modernizm, modernite ve Türkiye'nin kent planlama tarihi. Tarih Vakfı Yurt Yayınları.

Turan, Ö., \& Uluengin, M. B. (2005). İmparatorluğun ihtişam arayışından Cumhuriyet'in radikal modernleşme projesine: Türkiye'de kentsel planlamanın ilk yüz yıl. Türkiye Araștırmaları Literatür Dergisi, 3(6), 353-436.

Tuvalo, B. (1955). İstanbul şehri umumi planı. Beyoğlu-OrtaköyBeşiktaşs (APLBTISTNDX01) [Map]. SALT Online Archive. https://archives.saltresearch.org/handle/123456789/111072

Uluskan, S. B. (2007). Atatürk döneminde İstanbul'un imarı ve Henri Prost planının basındaki yankıları (1936-1939). Erdem, 16(48), 109156.

Ünal, N. (2011). Boğaziçi'nde dini yapılaşmanın tarihsel süreci bağlamında Arnavutköy yerleşimi ve Arnavutköy Sinagogu'nun incelenmesi [Master's Thesis]. Mimar Sinan Fine Arts University.

İstanbul'un imarı ve eski eser kaybı. (1968). In Türk Sanatı Tarihi Araştırma ve Incelemeleri (Vol. 2, pp. 6-61).

Üresin, M. (2019). Sermaye ve politikanın şehirleri yeniden üretmesi ve kamusal alanların dönüşümü: Beşiktaş örneği. [Master's Thesis]. İstanbul Technical University.

Yıldız, R., Senlier, N., \& Özyılmaz Küçükyağcl, P. (2018, March 21). Planning process of the İstanbul Bosphorus area, conflicts and challenges. Fifth International Symposium Monitoring of Mediterranean Coastal Areas: Problems and Measurement Techniques. Fifth International Symposium Monitoring of Mediterranean Coastal Areas: Problems and Measurement Techniques, Livorno, Italy.

1860-70 Map. (1860-1870). [Map]. http://istanbulurbandatabase.com 1882 Map. (1882). [Map]. http://istanbulurbandatabase.com 
Bosphorus Coastal Road and Settlements Between Beşiktaş and Bebek in 1939 Plan

1966, 1970, 1982, 2011, 2017 Aerial Photos. [Aerial Photos]. İstanbul Büyükşehir Belediyesi. https://sehirharitasi.ibb.gov.tr/

\section{Resume}

Dr. Sezgi Giray Küçük received her B.Arch from Mimar Sinan Fine Arts University in Architecture, M.Arch and PhD in Restoration from Istanbul Technical University. She currently works as an Assistant Proffesor at the Architectural Restoration Programme, Vocational School of Mimar Sinan Fine Arts University. Her fields of interest are Conservation, Renovation and Restoration, Materials in Architecture, History of Architecture and Art, Urban History, Urban Change and Transformation. 